\title{
Ciencia y Adab en el islam. Los espacios palatinos dedicados al saber*
}

\author{
Susana Calvo CaPilla \\ Departamento de Historia del Arte I \\ Universidad Complutense de Madrid \\ susana.calvo@ghis.ucm.es
}

\begin{abstract}
RESUMEN
Los primeros filósofos árabes asumieron el ideal de la humanitas y adoptaron a los sabios antiguos como modelo científico, educativo y cultural. Eran conscientes de que las "ciencias de los antiguos" (al- 'ulüm al-awā $i l$ ) eran la herencia común de la Humanidad y que la meta suprema del conocimiento era la filosofía ( $a d a b$ haqīqī o "educación verdadera"), que les permitía alcanzar el conocimiento (racional) de Dios. Adab, en su definición inicial y más amplia, designaba la educación humanística, concebida de manera muy similar a la paideia griega y a la humanitas latina. El conocimiento científico constituía una parte esencial de esa educación restringida a las élites (al igual que la paideia). Los gobernantes musulmanes, desde época omeya y sobre todo en el siglo IX, asumieron la educación, el cultivo de las ciencias y de la filosofía así como el impulso de las artes como pilares esenciales de su política y de su legitimidad como soberanos justos y perfectos, razón por la que crearon en sus palacios instituciones ligadas al saber. En ausencia de unas tipologías arquitectónicas claramente definidas, las descripciones de las fuentes escritas pueden ayudar en la identificación de los espacios destinados a la práctica y la salvaguarda del conocimiento en los palacios andalusíes conservados.
\end{abstract}

Palabras clave: Filosofía, Adab, Espejos de príncipes, Palacios islámicos, Bibliotecas, mâylis.

\section{Science and $a d a b$ in Islam. Palatial spaces for knowledge}

\begin{abstract}
The first Arab philosophers assume the ideal of Humanitas and adopted the Ancient wise men as scientific, educational and cultural models. They were aware that the "sciences of the Ancients" (al-'Ulum al-awa 'il) were the common heritage of humanity and that the ultimate goal of knowledge was the philosophy, which allowed attaining (rational) knowledge of God. Adab, in its initial and broader definition, designated the education, understood similarly as Greek Paideia and Latin Humanitas. Scientific knowledge was an essential part of that education restricted to the elite (like the Paideia). Muslim rulers from the Umayyad period and especially since the ninth century, assume the education, the cultivation of the sciences and the philosophy as well as promoting the arts as the essential pillars of its policy and its legitimacy as sovereigns righteous and perfect. They created institutions linked to knowledge in their palaces; In the absence of clearly defined architectural typologies, descriptions of written sources can help us in identifying potential spaces for practice and safeguarding of knowledge in the Andalusian palaces preserved.
\end{abstract}

Key words: Philosophy, Adab, Mirror for princes, Islamic palaces, Libraries, maŷlis.

* Este artículo forma parte del Proyecto I+D+i HAR2009-08901. 


\section{Renacimiento y Humanismo en Islam. La recuperación de las "ciencias de los Antiguos" en Bagdad y su irradiación hacia Occidente}

$A d a b$ es un término árabe que en su definición inicial y más amplia designa la educación concebida de manera muy similar a la paideia griega y a la humanitas latina. En época abbasí, el adab era sinónimo de una educación humanística y profana, de contenido ético, social e intelectual para la formación de la mente y el carácter, una educación basada en el ideal clásico de la filantropía o amor a los hombres. El adab, como la paideia, proporciona una educación civilizadora que persigue la perfección humana, una educación cuyo fin supremo, tanto en el mundo clásico como en el Islam, era la Filosofía, adab haqīqī o "educación verdadera" según lo llamaron los filósofos árabes. ${ }^{1}$ Esta educación, al igual que la paideia, estaba restringida a la élite, a una esfera muy concreta de la sociedad.

Aquellos filósofos árabes de los siglos VIII, IX y X asumieron el ideal de la $h u$ manitas y adoptaron a los antiguos clásicos como modelo educativo y cultural, según Kraemer. Son conscientes, y así se evidencia en la corte abbasí del siglo IX y X, de que las "ciencias de los antiguos" (al- 'ulüm al-awā'il) eran la herencia común de la Humanidad. Todos los intelectuales de la época insisten en una idea: "La educación es el mayor bien y el más elevado ideal humano". El conocimiento científico constituía una parte esencial de esa educación, si bien la meta suprema era la Filosofía, una sabiduría que, en definitiva, será interpretada como un signo divino porque permite alcanzar la unión o el conocimiento (racional) de Dios. ${ }^{2}$

Muchos son los autores que han estudiado este fenómeno de recuperación y asimilación de la cultura y la ciencia grecorromanas en la corte abbasí del siglo IX. La pregunta esencial es: ¿existió un Humanismo islámico? ¿Podemos hablar de "Renacimiento en el Islam"? Algunos investigadores lo han negado, reservando esa exclusiva a la cultura de la Europa medieval, a Occidente. Sin embargo, los magníficos estudios de Rosenthal, Gutas o Kraemer argumentan en sentido contrario al considerar que el mundo medieval islámico, durante los siglos IX y X, adoptó el ideal helenístico y grecorromano de la Humanitas. ${ }^{3}$ En consecuencia, no debemos hablar de un "humanismo islámico" sino de Humanismo a secas ${ }^{4}$. Para Rosenthal, el proceso que tuvo lugar en el corazón del imperio musulmán entre el siglo VIII y el X "está más cerca en espíritu y carácter del Renacimiento europeo que cualquiera de los movimientos a los que últimamente se ha aplicado ese nombre". ${ }^{5} \mathrm{El}$ árabe se convirtió en un lengua-

1 J.L. KRAEMER, "Humanism in the Renaissance of Islam: A preliminary study", Journal of the American Oriental Society, 104-1 (1984), pp. 135-164; F. ROSENTHAL (ed.), The Classical Heritage in Islam (Arabic Thought and Culture), London, 1994, pp. 1-14.

2 J.L. KRAEMER, op. cit., 1984, p. 151; P. LETTINCK, "Science in Adab literature", Arabic Sciences And Philosophy, 21-1, pp. 149-163.

3 D. GUTAS, Greek thought, Arabic culture: the Graeco-Arabic translation movement in Baghdad and early Abbāsid society (2nd-4th/8th-10th centuries), London, 1998. Ideas previamente defendidas por F. ROSENTHAL, op. cit., 1994, y J.L. KRAEMER, op. cit., 1984.

4 J.L. KRAEMER, op. cit., 1984, pp. 146-147.

5 F. ROSENTHAL, op. cit., 1994, pp. 1-14. 
je universal, lo que los griegos llamaron Koiné, y con él, la educación, la cultura o el estilo de vida que representaron una nueva oikoumene.

Decía el primer gran filósofo árabe, que aunó Islam y Razón, al-Kindi (801-873), que los musulmanes no debían avergonzarse de apreciar la verdad y adquirirla fuera cual fuera su procedencia, incluso si llegaba de naciones, razas y religiones diferentes. La búsqueda de la verdad no debe tener fronteras. Y así se evidencia en la integración de diversas tradiciones culturales, la árabe, la grecorromana, la persa o la hindú en ámbitos tan diversos como las ciencias, la política, los espejos de príncipes o el arte. ${ }^{6}$

La segunda acepción y más conocida de $a d a b$ es la que se refiere al género literario. Éste trata de recoger y sintetizar los conocimientos necesarios para tener una cultura general adecuada, básica, o simplemente para convertirse en un buen cortesano, un buen ciudadano o en un buen profesional. Los libros de adab tienen un contenido enciclopédico, docente y moralizante. Resumen los saberes y las ciencias universales en forma de sentencias e historias ejemplarizantes extraídas de contextos no religiosos, centradas en el "Hombre", en sus cualidades y sus pasiones. Suelen tener como protagonistas a personajes históricos preislámicos (desde Aristóteles y Platón a Cosroes, Ardašir o Alejandro Magno) y a los actores de los primeros tiempos del Islam (los califas ortodoxos y los primeros omeyas, especialmente Mu'awiya). Para Gabrieli, en ambas acepciones se resume en cierta medida la historia, origen y evolución de la cultura árabo-islámica desde su nacimiento ${ }^{7}$.

Poco a poco se introdujeron en el $a b a b$ conocimientos no árabes, extraídos del mundo iraní (épica, gnómica, tradición narrativa), de la literatura en sánscrito y de la filosofía griega (la ética, la economía y la política), lo que convirtió el género en un compendio de experiencias humanas con entidad propia y desprovistas de carácter religioso, una especie de mitografía específicamente arabo-islámica, según Bray. En ese sentido la literatura de $a d a b$ desempeñaba un papel activo en la sociedad y en la formación de la cultura propia ${ }^{8}$. En al-Andalus, la primera obra de $a d a b$ conocida y conservada es el Collar único de Ibn Abd Rabbihi, cortesano y panegirista de 'Abd al-Rahman III.

En la corte todo el mundo necesitaba una educación básica para estar junto al soberano, para desarrollar sus tareas y para medrar. Todos los cortesanos, los secretarios, los escribas o los propios sirvientes (masculinos y femeninos, puesto que las esclavas recibían una educación exquisita) debían tener una cultura urbana y humanística. Esta cultura básica humanística acabará siendo un sinónimo de ẓarf, elegancia, refinamiento. ${ }^{9}$

6 J.L. KRAEMER, op. cit., 1984, p.149. L. MARLOW, “Among Kings and Sages: Greek and Indian Wisdom in an Arabic Mirror for Princes", Arabica, 60 (2013), pp. 1-57.

7 F. GABRIELI, “Adab”, Encyclopaedia of Islam (2), Leiden, I, p. 175-6.

8 J. BRAY, "Abbasid myth and the Human Act: Ibn “Abd Rabbih and others", P. F. Kennedy (ed.), On Fiction and Adab in Medieval Arabic Literature, Wiesbaden, 2005, pp. 1-53. Entre los personajes que sirven de ejemplo, Ibn 'Abd Rabbih incluye anécdotas o frases de héroes de las Conquistas árabes $(f u t \bar{u} h)$ y de califas como Mu'awiya, 'Abd al-Malik o al-Ma'mun.

9 B. SORAVIA, “Les manuels à l'usage des fonctionnaires de l'administration (adab al-kātib) dans l'Islam Classique", Arabica, LII-3 (2005), pp. 417-436. C.E. BOSWORTH, “Administrative literature”, M.J.L. 
Con el tiempo, el significado y el contenido del Adab se fue encogiendo: ya no era "la cultura general que se espera de un hombre con educación superior", sino unos "conocimientos necesarios para desarrollar determinadas funciones en la corte". Por eso se empezó a hablar de "adab al-kätib" (manual de secretarios y de visires). Es decir, perdió su amplitud humanística y pasó a ser más superficial, a contener literatura, "Bellas-Letras", de manera más retórica, para aparentar ser culto sin llegar a serlo. ${ }^{10}$

Volviendo al sentido inicial de $a d a b$, el contenido de la educación seguía la clasificación aristotélica de las ciencias. Al-Farabi elaboró un curriculum propiamente árabe e islámico que supuso, según Kraemer, una espléndida síntesis de las ciencias antiguas y de las propias o árabes. En primer lugar era necesario estudiar Lingüística (gramática, sintaxis, escritura, lectura y poesía), que proporciona el dominio del lenguaje. Después Lógica (Logos), para acceder a un razonamiento coherente, un discurso elocuente y el uso de un lenguaje puro y unas expresiones nobles. Esta es la cultura básica que debería tener todo hombre cultivado, así como todo aquél que quisiera proseguir sus estudios y alcanzar un conocimiento más elevado.

En lo más alto del conocimiento están las Matemáticas (aritmética, geometría, óptica, astronomía, música, mecánica) y sólo una vez alcanzado ese nivel se podía abordar el estudio de la Física, la Metafísica y la Política (que incluía jurisprudencia y teología especulativa o kalam), es decir, la Filosofía. En ese programa están, por lo tanto, comprendidas las Siete artes liberales, el trivium (gramática, retórica y dialéctica) y el quadrivium (geometría, aritmética, astronomía, teoría de la música). ${ }^{11}$

\section{Aristóteles y la educación de los Príncipes}

La importancia de la filosofía clásica, y más en concreto de las enseñanzas aristotélicas, para ejercer un buen gobierno queda evidenciada en el sueño del califa alMa'mun: éste vio en sueños a Aristóteles sentado en una asamblea de filósofos ${ }^{12}$. Ibn al-Nadim cuenta el sueño en un capítulo de su libro donde explica la abundancia de libros clásicos traducidos al árabe en la corte de al-Ma'mun. Para Gutas el objetivo de esta narración estaba relacionado con la necesidad política de al-Ma'mun de reforzar su autoridad, fundamentada en la razón ( $\left.r a^{\prime} y\right)$, como preconizaba Aristóteles, y no en al Corán y la Sunna, como pretendían las élites religiosas. De ahí la pregunta que el califa hace al filósofo ¿cuál es el mejor discurso?, a lo que Aristóteles responde: "lo que sea correcto desde el juicio personal". ${ }^{13}$

Young, J.D. Latham et al. (eds.), Religion, Learning, and Science in the 'Abbasid Period, The Cambridge History of Arabic Literature, Cambridge, 1990, vol. pp. 165-167.

10 F. GABRIELI, op. cit., p. 176.

11 J.L. KRAEMER, op. cit., 1984, pp. 154-55.

12 Esta historia es transmitida por varias fuentes árabes, entre ellas el Fihrist de Ibn al-Nadīm (s. X) y por un discípulo de al-Fārābī. IBN AL-NADĪM (m. 995/998), The Fihrist of al-Nadīm. A Tenth-century survey of Muslim culture, B. DODGE (ed.y trad.), New York - London, 1970, pp. 594-606.

13 D. GUTAS, op. cit., 1998, pp. 95-104. El recurso a los sueños para exponer teorías morales o políticas tiene su origen, una vez más, en el mundo clásico. Cicerón insertó en su obra Sobre la República el "Sueño de Escipión", uno de los textos más leídos e influyentes de la Antigüedad. En el sueño, Escipión el Africano hacía 
En aquellos primeros pasos de la sociedad musulmana, los filósofos desempeñaron, al menos de manera teórica, el papel de consejeros regios e inspiradores de la educación de los príncipes. La literatura especular árabe nació en el siglo VIII, al final del período omeya, y derivaba de dos grandes tradiciones: la griega, basada en textos filosóficos, atribuidos en su mayoría a Aristóteles (384-322 a.C.) y relativos a su papel de maestro y guía de Alejandro Magno (356-323 a.C.) ${ }^{14}$; y la mesopotámica, a partir de textos persas y sasánidas que glosaban las virtudes políticas de los reyes iraníes (Ardašir, Cosroes, por ejemplo) y su corte de sabios. Ambas tradiciones se unirán en los primeros textos árabes en prosa, en su mayoría del género epistolar, cuyo contenido era esencialmente pedagógico o moralizante; se pretendía educar a los príncipes en las virtudes y en los principios morales y éticos, e iniciarlos en las artes de la guerra y en los conocimientos filosóficos.

El origen de la literatura sapiencial arabo-islámica puede estar, según Mario Grignaschi, en un conjunto de epístolas atribuidas a Aristóteles que fueron traducidas al árabe bajo el título de Rasā'il 'Arisțūtạlīis ilà l-Iskandar, Epístolas de Aristóteles a Alejandro $^{15}$. El impulsor de la traducción, según Ibn al-Nadīm, fue un secretario del califa omeya Hisham b. 'Abd al-Malik (724-743) llamado Salim Abu-1-'Ala', atribución que confirma Grignaschi en sus estudios. La supuesta correspondencia dirigida por Aristóteles a Alejandro Magno fue recogida en una novela epistolar helenística escrita a mediados del siglo VI (después de 517) por un autor ligado a una de las últimas escuelas herméticas griegas ${ }^{16}$. En opinión de Latham, estas Epistolas podrían derivar de todo un corpus de literatura griega antigua de época tardía cuyo protagonista era Alejandro Magno ${ }^{17}$, y del que formaban parte asimismo el Peri Kosmou (De Mundo) atribuido a Aristóteles ${ }^{18} \mathrm{y}$ el conocido Pseudocalístenes o Romance de Alejandro, una novela épica escrita posiblemente en el siglo III d.C. y originaria del Egipto helenizado (siglo I a.C.).

recomendaciones morales y explicaba cuestiones de carácter universal a su hijo adoptivo Escipión Emiliano. M.T. CICERÓN, El Sueño de Escipión, J. RAVENTÓS (trans.), Barcelona, 2004.

14 Ya en la cultura griega y helenística, las enseñanzas que recibió Alejandro Magno de Aristóteles se habían convertido en un conjunto de enseñanzas empleadas en la educación de los príncipes y de la élite, y por ello incluidas como parte de la paideia, junto a los textos homéricos.

15 M. GRIGNASCHI, "Remarques sur la formation et l'interprétatión du 'Sirr al-asrâr'", Pseudo-Aristotle The Secret of Secrets, Sources and Influences, W.F. RYAN and C.B. SCHMITT (eds.), London, 1982, pp. 3-7.

16 M. MARÓTH, "The Correspondence between Aristotle and Alexander the Great. An Anonymous Greek Novel in Letters in Arabic Translation", Acta Antiqua. Hungría, 45 (2005), pp. 231-315. Este autor piensa que la novela epistolar griega pudo ser escrita por alguien ligado a una de las escuelas de retórica de Siria, en torno al siglo VI d. C., lo que significa que sería un ejemplo de la última literatura clásica griega y de una de las últimas manifestaciones de esas academias filosóficas de tradición helena. Miklós MARÓTH, The Correspondence between Aristotle and Alexander the Great: An anonymous Greek novel in letters in Arabic translation, Piliscsaba, The Avicenna Institute of Middle Eastern Studies, 2006. Traducción reseñada por Dimitri GUTAS, “On Graeco-Arabic Epistolary 'Novels", Middle Eastern Literatures, 12 (2009), pp. 59-70.

17 J.D. LATHAM, "The beginnings of Arabic prose literature: the epistolary genre", Arabic Literature to the End of the Umayyad Period, A.F.L. BEESTON et al. (eds.), Cambridge History of Arabic Literature, Cambridge, 1983, vol. 1, 154-179.

18 "Sobre el mundo". Aristotelous Kai Philonos Peri Kosmou= Aristotelis de Mundo Liber, Ad Alexandrum. = Carta de Aristóteles a Alejandro sobre el sistema del mundo. Supuestamente Apuleyo hizo una traducción latina titulada "De mundo". 
El traductor, Salim Abu-1-'Ala', enriqueció el texto griego introduciendo numerosos elementos de origen persa sasánida, fundamentalmente en aspectos relacionados con la política y con la organización del ejército y de la administración (el papel de los visires, el soberano como juez de apelaciones), unos pasajes que parecen inspirados en obras en pahlavi como el Testamento de Ardašir. A su mano se debe igualmente la epístola octava, titulada al- Siyāsa al- 'àmmīya, "el gobierno general" o "las reglas generales de la política", considerada el primer speculum principis árabe ${ }^{19}$.

En la obra se perciben, por lo tanto, dos tradiciones distintas y dos concepciones de la figura de Alejandro. Las partes originales de la novela griega evidencian la influencia de las doctrinas del hermetismo helenístico, que convierten a Alejandro en un rey filósofo por sus virtudes militares y morales (adquiridas de las enseñanzas de Aristóteles), tal y como le había definido Plutarco (m. ca. 120 d.C.) en su biografía. La segunda influencia, en las partes añadidas por el traductor árabe, es la del hermetismo mesopotámico, que presenta al conquistador macedonio combatiendo contra los pueblos politeístas, haciéndoles convertirse al culto de un Dios anónimo y de múltiples nombres, tal y como Hermes Trimegisto ("el astrólogo") había predicado; para ello, Alejandro sigue los consejos de Aristóteles y usa los logoi e himnos herméticos que éste le enseñó ${ }^{20}$.

El interés de los califas omeyas por la tradición política persa y sasánida se muestra en otros ejemplos, como la traducción al árabe, por orden del propio Hišam b. 'Abd al-Malik, de una Historia de los Emperadores sasánidas, según noticia transmitida por Mas'udi ${ }^{21}$. Hay que recordar que el prestigio de los soberanos persas entre los califas omeyas y abbasíes tenía un precedente en la Grecia Clásica, donde Jenofonte de Atenas escribió a inicios del siglo IV a.c. una obra titulada Cyropaedia ("Educación de Ciro"), exaltando la figura de Ciro como gobernante ideal, un libro muy admirado por el propio Alejandro Magno 22 .

La impronta iraní de las Epistolas revela la familiaridad del traductor con las instituciones y cultura sasánidas, lo que para Grignaschi es signo evidente de que se trataba de un autor, seguramente de origen persa, perteneciente al diwān del califa; es decir, un consejero cercano al poder con capacidad para hacer este tipo de recomendaciones políticas ${ }^{23}$. A ello sumaba Salim Abu-1-'Ala' una buena formación en literatura y filosofía griegas, lo que implica asimismo, un ambiente propicio para la recuperación del pasado clásico en la corte omeya de inicios del siglo VIII. La traducción de estas Epístolas, según Grignaschi, respondía a un ambicioso objetivo por parte del autor: hacer accesible a Hišam b. 'Abd al-Malik la ciencia y la moral helenas

\footnotetext{
19 M. GRIGNASCHI, "La figure d'Alexandre chez les Arabes et sa genèse", Arabic Sciences and Philosophy, 3 (1993), pp. 225-230.

20 M. GRIGNASCHI, op, cit., 1993, pp. 205-34.

21 M. GRIGNASCHI, "Les "Rasā'il 'Arisțāțāīsa ilā-l-iskandar" de Sālim Abū-1-'Alā et l'activité culturelle à l'époque omayyade", Bulletin d'études orientales, 19 (1965-66), pp. 7-83, esp. p. 25.

22 C. NADON, Xenophon's Prince: Republic and Empire in the Cyropaedia, Berkeley, 2001, pp. 6-25.

23 Los mss. de las bibliotecas Aya Sofya y Fátih se corresponden exactamente con la obra que Ibn alNadīm atribuyó a Sālim Abū-1-'Ala'; las partes XI y XII de esta novela inspiraron a lbn al-Muqaffa'. La descripción que encontramos en al-Siyāsa al- 'àmmīya sobre las instituciones políticas y militares del imperio árabe y de la situación en la frontera oriental sólo pueden referirse al califato de Hisham.
} 
con el fin de convencerle de la utilidad política de esas disciplinas y de la necesidad de cultivar los saberes de los antiguos, así como de proteger y admitir a los filósofos entre sus consejeros ${ }^{24}$, una idea que argumentará dos siglos más tarde el filósofo aristotélico al-Farabi (m. 339/950). Según Bennison, los abasíes culminaron esta política cultural con el propósito de afianzar la legitimidad califal mediante la construcción de un corpus arabo-islámico de conocimiento, es decir, de una cultura propia y nueva ${ }^{25}$.

De las Epístolas pseudo-aristotélicas derivaron otras obras que se pueden clasificar como literatura especular ${ }^{26} \mathrm{o}$ del género de adab: el al-siyāsa fì tadbīr al-ri 'āsah, centrado en los consejos de buen gobierno del original ${ }^{27}$, y el famoso Sirr al-Asrār Secreto de Secretos, traducido al latín más tarde. Del Sirr existen dos versiones de diferente extensión; la versión corta fue escrita a finales del IX o inicios del s. X, en todo caso con anterioridad a otra colección de epístolas de contenido enciclopédico conocida como Rasā'il Ijwān al-Șafā'o Epistolas de los Hermanos de la Pureza, en las cuales se pueden identificar elementos comunes al Sirr. La redacción larga del Sirr, por su parte, posee múltiples adiciones y suele datarse en el siglo XI ó XII ${ }^{28}$. Quizá ambos libros, el Kitāb al-siyāsa y el Sirr al-Asrār, e incluso las Rasā'il Ijwān al-Ṣafā'tengan una fuente común, un texto derivado de las epístolas pseudoaristotélicas mencionadas más arriba.

En las primeras versiones de aquellas epístolas de inspiración aristotélica se adivina una función didáctica y un mensaje dirigido a las élites gobernantes: se recomendaba al soberano proteger a los sabios y a los estudiantes, se exaltaba la Grecia clásica y se elogiaba el cultivo de las ciencias como medio de alcanzar el conocimiento más elevado. Más tarde (al menos desde el siglo XI), las obras inspiradas por las Rasā' $i l$, amplia y rápidamente difundidas por todo el mundo islámico, se interesaron más en subrayar y enriquecer su contenido hermético y ocultista, en detrimento de las doctrinas políticas y morales del texto original. Los ocho capítulos o discursos de

24 M. GRIGNASCHI, op. cit., 1965-66, p. 45. En el primer capítulo de las Rasa'il se dice: « Or, les savants el les philosophes se réunissaient dans une ville des 'Roum' appelée Athènes. À cette époque-là, leur chef était Aristote qui, en apprenant la nouvelle qu'Alexandre avait atteint l'âge de recevoir une instruction, écrivit à son père pour l'inciter à apprendre la philosophie à son fils.». Ibíd., 27.

25 A.K. BENNISON, The Great Caliphs: The Golden Age of the 'Abbasid Empire, New Haven, 2009, pp. 193-94.

26 Sobre los primeros espejos de príncipes árabes: C.E. BOSWORTH, "An Early Arabic Mirror for Princes: Tâhir dhû 1-Yamînain's Epistle to His Son 'Abdallâh (206 / 821)", Journal of Near Easter Studies 29 (1970), pp. 25-41; y op. cit. 1990, pp. 165-167; P. CRONE, "Did al-Ghazāl̄̄ write a Mirror for Princes? On the Authorship of Nașīhat al-Mulūk", Jerusalem Studies of Arabic and Islam, 10 (1987), pp. 167-197; y J.A. GARCÍA-JUNCEDA y R. RAMÓN GUERRERO, "La vida de Aristóteles de Abū Sulaymān alSijistānı”, Anales del Seminario de Historia de la Filosofía, 7 (1989), pp. 25-36. Antes de finales del siglo X, los traductores sirio-árabes, en particular Hunayn b. Ishaq (809-873), tradujeron los florilegios de máximas que, desde la Antigüedad, se atribuían al rey macedonio (apotegmas, sentencias breves y con un contenido moralizante subyacente). También trasladaron al árabe una recopilación de frases pronunciadas por los filósofos en el entierro de Alejandro (con una visión negativa de sus guerras). M. GRIGNASCHI, op. cit., 1993 , p. 205.

27 La primera obra fue traducida al turco por Nevali, en el siglo XVI, de una antología árabe.

28 La versión larga del Sirr al-Asrar fue traducida al latín y está en el origen del Secreto de Secretos o Poridat de Poridades. El autor de esa traducción enriqueció el texto y lo adornó, desarrollando mucho más la parte dedicada al ceremonial y la pompa regia con elementos del área hindú. 
Aristóteles sobre el arte de gobernar que componían el Sirr pasan a un segundo plano en beneficio de su contenido mágico y esotérico. Sólo en los círculos intelectuales seguían interesando las enseñanzas sobre el buen gobierno político ${ }^{29}$.

La rápida difusión de estas obras y su llegada a la Europa cristiana a través de alAndalus (al menos desde el siglo $\mathrm{X}^{30}$ ) se debía, como ha estudiado J. Dakhlia, a su vocación universalista, que las hacía independientes del contexto dinástico en el que se crearon. Además, los consejos acaban siendo válidos no sólo para el soberano, sino también para los cortesanos y las élites, lo que justifica su conversión en antologías de $a d a b .{ }^{31}$

La corriente de admiración por la filosofía clásica, en especial por la obra aristotélica, así como los primeros libros sapienciales protagonizados por Aristóteles y Alejandro Magno debieron llegar tempranamente a al-Andalus. Aquellos textos constituyeron la principal fuente de información sobre la vida del filósofo y del conquistador macedonio, a menudo situados entre la historia y el mito. Ambos suelen aparecer en las obras de adab y en los diccionarios bio-bibliográficos andalusíes de los siglos X y XI. Los autores andalusíes de época califal parecen conocer, al menos en parte, el enorme corpus de conocimientos reunido en Bagdad, conformado por los libros griegos y persas traducidos al árabe y por los aportes científicos y filosóficos realizados por los autores musulmanes. Los viajes a Oriente, la llegada de sabios y de libros desde Bizancio o desde tierras del califato oriental, así como la traducción de copias en latín que circulaban por la Península, permitieron el acceso de los autores andalusíes a las obras grecolatinas y a las de los filósofos árabes ${ }^{32}$. Sólo así puede entenderse que el médico cordobés Ibn Yulyul tuviera acceso, en el momento de redactar su diccionario de médicos y sabios (concluido en 377/987), a las obras de Hipócrates, Dioscórides, Platón, Aristóteles, Galeno, Orosio, Eusebio de Cesárea, San Isidoro de Sevilla y al-Kindi, y que incluyera las biografías de Sócrates, Demócrito, Ptolomeo y Euclides. En su Diccionario de médicos (Tabaqāt) aparece una de las menciones más antiguas del Sirr al-asrār, incluida en la biografía de Aristóteles ${ }^{33}$. Ya antes, el también cordobés Ibn 'Abd Rabbihi (Córdoba, m. 940) abría su 'Iqd al-Farīd o Collar único, el primer libro andalusí de $a d a b$, con un capítulo de consejos morales y

29 El análisis de las tres obras y de sus diferentes tradiciones y copias, en M. GRIGNASCHI, op. cit. 1982. Para las copias que circulan en época de Alfonso X: A. RUCQUOI and H.O. BIZZARRI, "Los Espejos de Príncipes en Castilla: entre Oriente y Occidente", Cuadernos de historia de España, 79-1 (2005), pp. 7-30.

30 R. RAMÓN GUERRERO, "Textos de al-Farabi en una obra andalusí del siglo XI: "Gayat al-Hakim" de Abu Maslama al-Mayriti”, Al-Qantara, 12-1 (1991) p.3-17; y La recepción árabe del 'De Anima' de Aristóteles: al-Kindi y al-Farabi, Madrid, 1992.

31 J. DAKHLIA, “Les Miroirs des princes islamiques: une modernité sourde?", Annales. Histoire, Sciences Sociales, 57-5 (2002), pp. 1191-1206.

32 M.J. VIGUERA, "Bibliotecas y manuscritos árabes en Córdoba”, Al-Mulk, 5 (2005), pp. 101-106.

33 La Crónica griega de Eusebio de Cesárea fue traducida al árabe de su versión latina en época de al-Hakam II. Sobre las fuentes: J. VERNET, "Los médicos andaluces en el 'Libro de las Generaciones de Médicos', de Ibn Ŷulŷul", Anuario de Estudios Medievales, 5 (1968), pp. 455-63 (450-51). IBN ŶULŶUL, Tabaqat al-atibba' wa al-hukama' = Les générations des médecins et des sages, F. SAYYID (ed.), al-Qahira, 1955. J.A. GARCÍA-JUNCEDA y R. RAMÓN GUERRERO, "La vida de Aristóteles de Ibn Ŷulŷul", Anuario del Departamento de Historia de la Filosofia y de la Ciencia (1984), pp. 109-123. 
políticos a los gobernantes donde reunía anécdotas extraídas de la literatura especular protagonizadas por Aristóteles y Alejandro el Macedonio. ${ }^{34}$

Un capítulo destacado en la literatura especular árabe es la Justicia (en árabe 'adl), que en las epístolas aristotélicas es encarnada por Alejandro. El soberano y el Estado deben garantizar el principio de equidad en la sociedad. Esta idea se repite de forma recurrente en los textos, "mejor el gobierno de un príncipe infiel y justo que la iniquidad de un soberano musulmán", llega a decir al-Gazali ${ }^{35}$.

Las citadas Rasā'il o Epistolas de Aristóteles a Alejandro, el Sirr al-Asrār, la famosa Mujtār al-hikam (Máximas selectas y los dichos mejores traducida al castellano como Bocados de Oro) de al-Mubaššir b. Fatik ${ }^{36}$ (s. XI), así como todas aquellas obras que incluían una biografía de Aristóteles, recogían ocho máximas sobre la justicia atribuidas al filósofo griego y supuestamente dirigidas a Alejandro ${ }^{37}$. Los ocho discursos aristotélicos sobre la justicia y la política, que se repiten con escasas variaciones desde el siglo X, eran, según Ibn Yulyul:

"El mundo es un jardín (bustān), cuyo vallado es el Estado (al-dawla).

El Estado es una potencia, a la que ampara la ley.

La Ley es una regla de gobierno, que dirige el rey (al-malik).

El Rey es un pastor, al que ayuda el ejército.

El ejército es un cuerpo auxiliar, al que mantiene el dinero (al-māl).

El dinero es un medio de subsistencia, que suministran los súbditos.

Los súbditos son siervos, a los que protege la justicia $\left(a l-{ }^{\prime} a d l\right)$.

La justicia es una costumbre, que es el buen orden del mundo (al- 'âlam)". ${ }^{38}$

Estos ocho aforismos aristotélicos, conocidos como el "Octógono" o el "Círculo de la Justicia", solían ir acompañados de una ilustración: un círculo o un octógono en el que aparecían inscritos ${ }^{39}$ (fig. 1). Algunos autores añaden que las ocho máximas

34 'ABD RABBIHI, The Unique Necklace, al- 'Iqd al Farīd, I.J. BOULLATS (trad.), Reading, 2007, vol. I, pp. 16-17, 89, 155. J. VEGLISON, El collar único de Ibn Abd Rabbihi, Madrid, 2007, pp. 92-93.

35 Frases extraídas de AL-GAZALI, Counsels for Kings, F.R.C. BAGLEY (trad.), Londres-New York, 1964; Cfr. A.K.S. LAMBTON, "The Theory of Kingship in the Nasthat al-Mulûk of Ghazali", The Islamic Quarterly, I (1954), pp. 47-55; y J. DAKHILA, op. cit., 2002, p. 1199. La preocupación personal de los soberanos por ser justos (más allá de la justicia divina) se manifiesta en la celebración de audiencias y la creación de instituciones como la del juez de apelaciones, ejercida por el propio califa al principio (en alAndalus se crea en el siglo IX, a imitación de la abasí). Los cronistas insisten a menudo en este principio de equidad de los soberanos.

36 El médico, filósofo, historiador y bibliófilo sirio-egipcio Abū 1-Wafa' al-Mubaššir ibn Fatik reunió una colección de Las máximas selectas y los dichos mejores hacia 1048 o 1049. La versión castellana se tituló Bocados de oro, AL-MUBAŠŠIR, Mujtār al-hikam wa-mahāsin al-kalim, A. BADAWI (ed.), Madrid, 1958, pp. 178-222. También lo hace el bagdadí Abū Sulaymán al-Siyistanī (m. ca. 985-990), a quien se atribuye la obra titulada Siwān al-Hikma (= El armario de la sabiduria), véase J.A. GARCÍA-JUNCEDA y R. RAMÓN GUERRERO, op. cit., 1989, pp. 25-36.

37 D. GUTAS, "The spurious and the authentic in the Arabic lives of Aristotle", J. KRAYE et al. (eds.), Pseudo-Aristotle in the Middle Ages. The Theology and others texts, London, 1986, pp. 15-36.

38 J.A. GARCÍA-JUNCEDA y R. RAMÓN GUERRERO, op. cit., 1984, pp. 109-123.

39 Los manuscritos de la Muqaddimah de IBN JALDUN, que también lo recoge, suelen dejar un espacio vacío para insertar el círculo en el que se decía que estaban inscritos los ocho discursos. Un bello dibujo de un octógono inscrito aparece en el manuscrito de Istanbul del Secretum, Reis el-Kuttap (Asir 1), 1002, fol. 121b. (Cf. Frontispiece, Vol. 2.). Trad. de Rosenthal en la Introducción de la Muqaddima. (Princeton, 1967). 


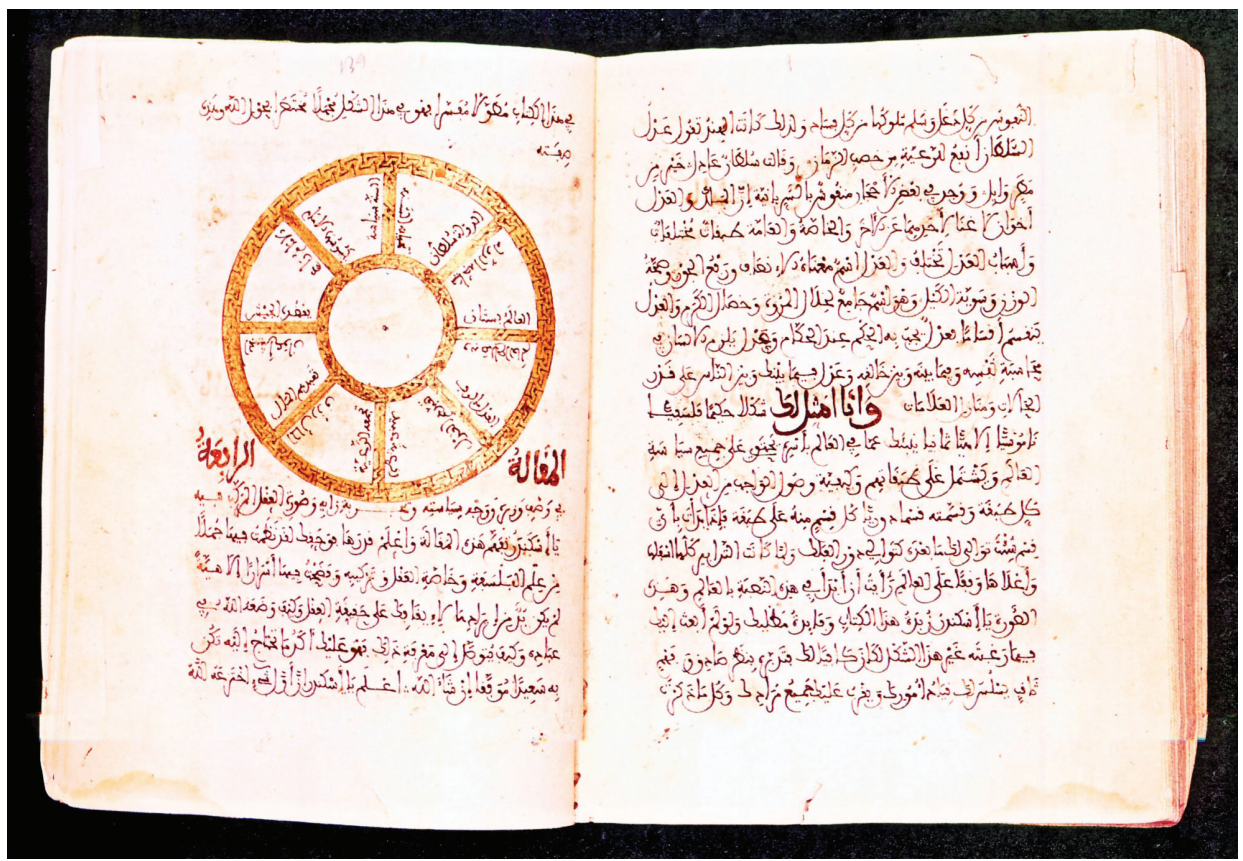

Fig. 1. La Política de Aristóteles al-Siyāsa fì tadbīr al-Ri 'āsa. Sirr al-asrār. Mss. de Marruecos 1488-1489. Papel, tinta, oro, 25 x 21 cm. Rabat, Biblioteca Real, nº. inv 586.

también fueron inscritas en la tumba del propio Aristóteles. Dos de los autores más antiguos en mencionarlo son los andalusíes Ibn Yulyul (finales del s. X) y Sa'id alAndalusi (mediados del s. XI), que incluyeron una descripción de aquella supuesta tumba. Ibn Yulyul dice:

“Cuando Aristóteles murió fue enterrado y sobre él se edificó una cúpula octogonal (=qubba mutammanat), sobre la que se inscribió (yukatiba), en cada uno de sus lados, cada uno de estos ocho discursos ( $f \grave{\imath}$ kulli ŷānib minhā kalima min al-kalimāt)". ${ }^{40}$

Por su parte, Sa'id al-Andalusi incluía en su Kitāb țabaqāt al-umam, según Blachère, lo siguiente:

“Cuando llegó la hora de su muerte le dijo a sus discípulos: 'Cuando me haya ido haréis grabar sobre cada uno de los lados de mi tumba octogonal una de estas máximas $[\ldots]^{\prime 4}$.

40 IBN ŶULŶUL, op. cit., 1955, p. 26.

41 ȘĀ'ID AL-ANDALUSĪ, Kitāb țabaqāt al-umam= Libro de las categorías de las naciones, E. LLAVERO RUIZ Y A. MARTÍNEZ LORCA (trad. y notas), Madrid, 2000, pp.87-88. R. Blachère inserta en su traducción este pasaje sobre la vida de Aristóteles, perdido en los manuscritos del Tabaqat al-umam pero 


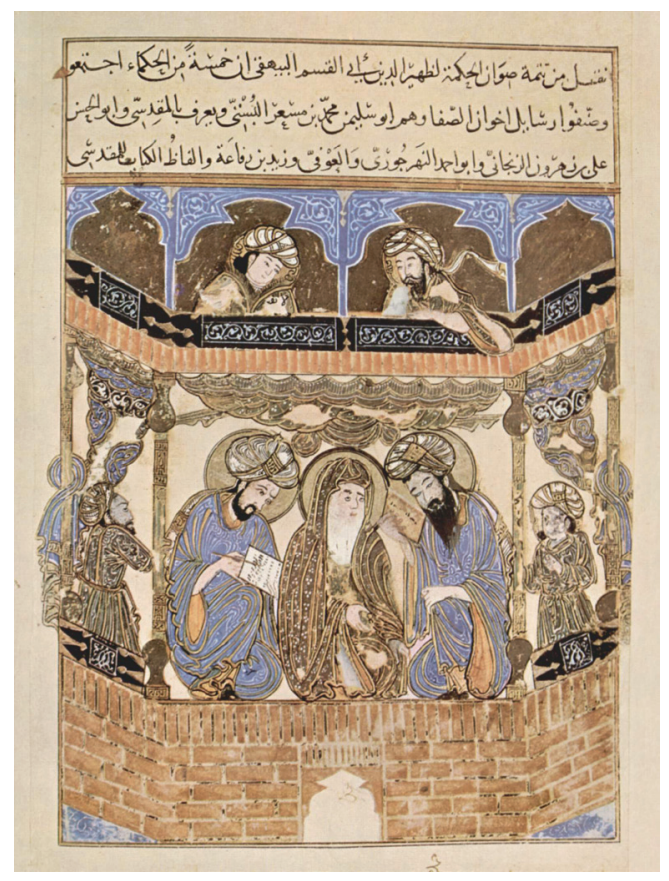

Fig. 2. Manuscrito iluminado de Las Epístolas de los Hermanos de la Pureza, completado en Bagdad en 1287. Biblioteca de la Mezquita Suleymaniye de Estambul (Turquía), Mss. Esad Efendi 3638, (fol. 4r).

Desgraciadamente, ningún manuscrito, que sepamos, ha conservado una ilustración de esa supuesta tumba octogonal de Aristóteles.

Es importante señalar que los manuscritos más lujosos de las obras del género especular y de adab estaban probablemente ilustrados con miniaturas desde el siglo IX y $\mathrm{X}^{42}$. Dichas imágenes no se han conservado pero sí otras posteriores, como el manuscrito bagdadí de las Rasā'il Ijwān al-Safā' o Epístolas de los Hermanos de la Pureza, del siglo XIII ${ }^{43}$ (fig. 2). En una de las ilustraciones se ve a un grupo de sabios reunidos en torno a un maestro -Aristóteles, probablemente-, y aunque se realizó con un lenguaje plenamente islámico, la inspiración del grupo hay que buscarla en las miniaturas de los manuscritos científicos y filosóficos antiguos que circulaban por las bibliotecas del mundo islámico, como el magnífico Dioscórides de Viena (ca.

conservado gracias a la Ihāta de Ibn al-Jațīb. Livre des catégories des nations = Kitāb tabaqāt al-umam, RE. BLACHËR Y L. CHEIKHO (trad. y ed.), Paris, 1935, pp. 67-68.

42 D.S. RICE, "The Oldest Illustrated Arabic Manuscript", Bulletin of the School of Oriental and African Studies 22-1 (1959): 207-220.

43 P. BERLEKAMP, Wonder, Image, and Cosmos in Medieval Islam, New Haven-London, 2011, pp. 5054, 120-30. Berlekamp recoge noticias sobre el origen de las ilustraciones de obras astronómicas y el caso de este manuscrito iluminado de las Epístolas de los Hermanos de la Pureza, completado en Bagdad en 1287 (Suleymaniye Library, Istanbul, Turkey). 


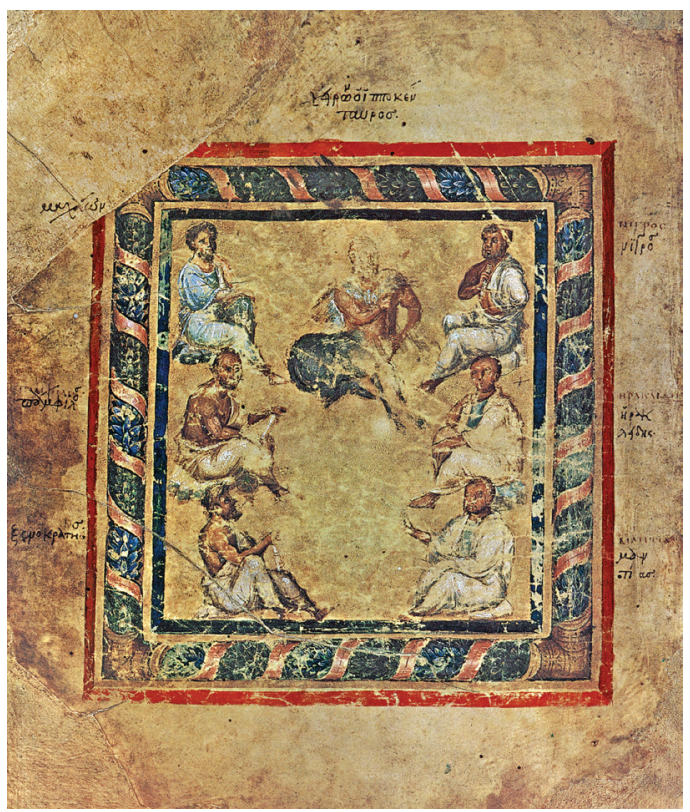

Fig. 3. Médicos en torno a Galeno. De Materia Medica de Dioscorides. Manuscrito ilustrado ca. 515 para la princesa bizantina Juliana Anicia. Biblioteca Nacional de Austria, Viena. (fol. 3 v).

515, Biblioteca de Viena) (fig. 3). ${ }^{44}$ Las reuniones de sabios, en escenarios diferentes, vuelven a aparecer en las obras de Alfonso X, en cuyo Lapidario se representa de nuevo a Aristóteles rodeado de sabios y donde, a diferencia de otras miniaturas, el propio rey es un personaje secundario situado debajo del filósofo.

Encontramos otro testimonio de la presencia de ilustraciones en un manuscrito anónimo aljamiado del Rrekontamiento del rrey Ališandre (s. XVI) conservado en la Biblioteca Nacional de Madrid (MSS/5254); en él no se reprodujeron las $32 \mathrm{mi}-$ niaturas que contenía el original árabe, probablemente del s. XIII, pero en cambio sí se copiaron los textos explicativos en árabe y aljamiado y a tinta roja ${ }^{45}$. Una de las miniaturas consistía en la "imagen de Dū-l-Qarnayn (Alejandro Magno) y delante de él la compañía de Gog y Magog y había en su mano su espada para herirlos". ${ }^{46}$

44 M.J. ROGERS, "Text and illustrations. Dioscorides and the illustrated herbal in the Arab Tradition", Arab Painting: Text and Image in Illustrated Arabic Manuscripts, A. CONTADINI (ed.), Leiden, 2010, pp. 41-47.

45 Z.D. ZUWIYYA, “ficha de catálogo no 49”, Memoria de los Moriscos, Madrid, 2010, pp. 210-12; A.R. NYKL, "Aljamiado literatura El Rrekontamiento del Rrey Alisandre", Revue hispanique, 77/ 172 (1929), pp. 409-611. Z.D. ZUWIYYA, Islamic Legends Concerning Alexander the Great: Taken from Two Medieval Arabic Manuscripts in Madrid, Binghamton-New York, 2001.

46 "Sūratu la fegura D̄i-l-qarneini wa quddāmahu i delante del ğamāctun konpanna de lo de Ğūği wa Māğūği wa huwa i-el qad rafaca ke ya abia yadahu su mano bi çeifihi kon su spada li yiḍrabahum para ferirlos bihi kon el.", A.R. NYKL, op. cit., 1929, p. 480. 


\section{El soberano y sus sabios. EI cultivo de la ciencia y del saber como base del Poder}

Al-Ma'mun y los califas abasíes que le sucedieron a lo largo del siglo IX entendieron la trascendencia del cultivo de las artes y de las ciencias como elemento de prestigio. Al igual que habían hecho anteriormente los reyes ptolomeos y sasánidas, los abasíes emprendieron una ambiciosa empresa cultural basada en la apropiación de la herencia de la Antigüedad y en la creación de un círculo de sabios y filósofos en la corte. El atesoramiento del saber de los Antiguos, su conservación y el impulso del conocimiento fueron una parte esencial de la política del Califato, un instrumento de legitimación y refuerzo de su soberanía. ${ }^{47}$

En el origen de la filosofía árabe sobresalen dos nombres, al-Kindi (m. en Bagdad, ca. 870), conocido como "el filósofo de los árabes", y al-Farabi (m. en Damasco en 950), filósofo aristotélico llamado "el segundo maestro" (siendo Aristóteles el primero). Al-Kindi fue el primero que intentó armonizar la razón filosófica y la doctrina islámica, al tiempo que ejercía de traductor y editor de obras científicas griegas en Bagdad $^{48}$. Al-Farabi ${ }^{49}$, por su parte, desarrolló la primera teoría política completa partiendo de la idea expuesta por Platón en la República, a saber, que el gobernante supremo, en condiciones óptimas, es el filósofo-rey ${ }^{50}$. Los filósofos, los intelectuales, en definitiva, los que tienen ideas en materias sublimes serían los gobernantes perfectos, pero como esa situación es utópica, lo mejor es, según al-Farabi, que el soberano se apoye en sus consejos para gobernar.

En al-Andalus, el principal impulsor del movimiento de recuperación de los saberes de los antiguos fue al-Hakam II, si bien su labor de bibliófilo y de mecenas de las ciencias y las artes comenzó aún en vida de su padre, 'Abd al-Rahman III, tal y como evidencian las fuentes escritas ${ }^{51}$. Ambos califas fueron conscientes de los beneficios de cultivar y estimular las ciencias y de apropiarse de la herencia cultural hispana de manera que pudiera crearse un corpus de saberes andalusíes y, con él, de una identidad nacional e independiente que legitimara la asunción del título califal y el ejercicio del poder supremo. Dentro de esa política cultural, la educación de los príncipes constituyó un punto de vital importancia. Tanto al-Hakam II como su hijo, el príncipe Hišam, recibieron una educación exquisita, con los mejores maestros en cada materia (incluidas las ciencias) y, al igual que en la corte abasí, siguiendo un programa o un currículo muy similar al mencionado antes, según la clasificación aristotélica de las

47 S. CALVO CAPILLA, "Reuse of Classical Antiquity in the Palace of Madinat al-Zahra' and Its Role in the Construction of Caliphal Legitimacy", Muqarnas, 31 (2014), en prensa.

48 Véanse las notas de A. Martínez Lorca en ȘA'AD AL-ANDALUSĪ, op. cit., 2000, pp. 123-124.

49 En al-Andalus se conocieron tempranamente sus obras (probablemente desde la segunda mitad del siglo X), en concreto el Fușūl muntaza 'a ("Aforismos selectos") y el Kitāb al-Madīnat al-fadila ("Libro de la Ciudad Perfecta”). R. RAMÓN GUERRERO, “Textos de al-Farabi en una obra andalusí del siglo XI: "Gayat al-Hakim" de Abu Maslama al-Mayriti", Al-Qanțara, 12-1 (1991), pp. 3-17.

50 Joel Kraemer, apud S. STROUMSA, "Philosopher-king or philosopher-courtier?,” C. DE LA PUENTE (ed.), Identidades marginales, Madrid, 2003, pp. 433-59 (443).

51 Hubo un capítulo previo, aunque con menor amplitud, de interés por las ciencias de los Antiguos en la corte cordobesa: en época de 'Abd al-Rahman II (822-852). 
ciencias. Al-Hakam II instaló una escuela palatina en Madinat al-Zahra', según indica el Muqtabis de Ibn Hayyan. ${ }^{52}$

En esta ocasión no insistiremos sobre el período califal; nos interesa más señalar que dicha política de impulso a las ciencias y las artes tuvo su continuidad en los reinos de taifas surgidos en el siglo XI y, posteriormente, en el Califato almohade (s. XII-XIII).

En algunos de los reinos taifas se llevaron a la práctica política aquellos mismos principios. Según Forcada, si en algún lugar dio frutos el cultivo de las Ciencias de los Antiguos, si en algún lugar consiguieron acercarse al ideal platónico recogido por al-Farabi de un "Rey-Filósofo", fue en el reino de los Banu Hud de Zaragoza en la segunda mitad del siglo $\mathrm{XI}^{53}$. La existencia de tan elevado clima científico en la corte hudí, fundamentado en la filosofía y las matemáticas, no se puede explicar sin tener en cuenta lo que supuso la política cultural califal, sin su biblioteca y sin los sabios reunidos en Córdoba. Al-Muqtadir (r. 1046-1082) atrajo a su corte a los maestros más sobresalientes y puso en marcha la mejor escuela posible para sus hijos. La actividad científica desarrollada por su sucesor, al-Mu’taman (r. 1082-1085), filósofo y autor de uno de los tratados matemáticos más importantes de los conservados en al-Andalus, hace suponer que su educación siguió la versión árabe, ya mencionada, de la clasificación aristotélica de las ciencias. Forcada se interroga sobre la manera en que pudo materializarse en la corte de Zaragoza ese ideal filosófico de la ciudad ideal de al-Farabi, sobre si fue más allá de la excepcional inclinación hacia el estudio de las ciencias en la corte, y sobre su uso como elemento de prestigio. En el palacio de la Aljafería, tal y como avanzó Robinson, sin duda se reflejó aquel ambiente erudito de la corte ${ }^{54}$. Los salones y pórticos conservados, escenarios quizá de reuniones poéticas y científicas, presentan composiciones arquitectónicas y decorativas inéditas que parecen estar materializando no sólo metáforas poéticas sino algunas de las especulaciones matemáticas y filosóficas desarrolladas por el rey y sus sabios en los maŷālis palatinos, tal y como más tarde sucederá en el Patio de los Leones de la Alhambra de Granada ${ }^{55}$.

52 IBN HAYYAN, Anales palatinos de al-Hakam II por Isa ibn Ahmad al-Razi (360-364H/971-975JC.) (Muqtabis VII), E. GARCÍA GÓMEZ (trad.), Madrid, 1967, pp. 98-99; IBN HAYYAN, Muqtabis VII, HĀ $\hat{Y} \hat{Y} \bar{I}$ (ed.), Beirut, 1965, p. 76. Véase S. CALVO CAPILLA, op. cit., 2014.

53 M. FORCADA, Ética e ideología de la Ciencia. El médico-filósofo en al-Andalus (siglos X-XII), Almería, 2011, pp. 219-34. El esplendor científico de los Banū Hūd en la taifa zaragozana ha sido estudiado por J. BOSCH VILÁ, "El reino de Taifas en Zaragoza. Algunos aspectos de la cultura árabe en el valle del Ebro", Cuadernos de Historia Jerónimo Zurita, 10-11 (1960), pp. 7-67; J. LOMBA, La filosofía islámica en Zaragoza, Zaragoza, 1987; y J. VERNET, "El Valle del Ebro como nexo entre Oriente y Occidente", Boletín de la Real Academia de Buenas Letras de Barcelona, 23 (1950), pp. 249-286.

54 C. ROBINSON, In praise of song: the making of courtly culture in Al-Andalus and Provence, 10051134 A.D., Leiden, 2002; y "Seeing Paradise: Metaphor and Vision in taifa Palace Architecture" Gesta, 36-2 (1997), pp. 145-155.

55 C. EWERT, Spanisch-islamische Systeme sich kreuzender Bögen. 3, Die Aljafería in Zaragoza, Berlín, 1978-1980; S. CALVO CAPILLA, "El arte de los Reinos Taifas: tradición y ruptura", Anales de Historia del Arte, Vol. Extraordinario 2 (2011), pp. 69-92. Sobre la presencia en los azulejos de la Alhambra de los grupos cristalográficos planos (Teorema de Fedorov) y de los "cuasicristales" descubiertos por Daniel Shechtman, véase R. PÉREZ GOMEZ, P. GUTIERREZ CALDERÓN y C. RUIZ GARRIDO, "La búsqueda 
A pesar de la fama de rigoristas con la que los almohades han pasado a la historia, la figura del segundo califa, Abu Ya'qub b. Yusuf (1163-1184), sobresale en las fuentes y en la historiografía como un soberano ilustrado, hasta el punto de ser comparado con al-Hakam II. Los cronistas almohades ensalzan su extraordinaria formación, su afición por la astronomía (que no astrología, denostada por los "unitarios") y por los libros.

En el Kitāb al-Mu'ŷib de 'Abd al-Wahid al-Marrakusi (m. 1224) se relata en extenso el interés de Yusuf I por el conocimiento. Dice al-Marrakusi que tenía grandes conocimientos de fiqh, de adab y de gramática. Luego, "su nobleza de alma y sus elevadas aspiraciones" le llevaron a interesarse por las distintas ramas de la filosofía. Empezó después con la medicina y aprendió de memoria numerosos libros. Además mandó reunir los libros de las distintas especies de filosfía, de manera que "consiguió atesorar casi tantos libros como los que reunió al-Hakam al-Mustansir bi-llah, el Omeya". De sus palabras parece deducirse de nuevo que recibió una educación basada en las artes liberales y que siguió el orden recomendado por los Antiguos. Acaba el capítulo diciendo:

\footnotetext{
"No cesó -Yusuf - de reunir libros de las regiones del Andalus y del Magrib, y de buscar sabios, especialmente los de la ciencia especulativa ('ilm al-nazar), hasta que reunió más de los que había reunido ninguno de los reyes del Magrib antes de él." ${ }^{56}$
}

Al-Marrakusi incluye asimismo las biografías de Ibn Tufayl e Ibn Rusd, donde indica que Yusuf I mantenía discusiones con Ibn Rusd (Averroes) sobre la eternidad del mundo y que incluso instigó a ambos a hacer el comentario de las obras de Aristóteles ${ }^{57}$; además, mandó que se extractaran las obras de los principales filósofos clá$\operatorname{sicos}^{58}$. Estas palabras podrían parecer un simple panegírico que pretende equiparar al califa almohade con al-Hakam II. Sin embargo, las propias obras de Ibn Tufayl y de Ibn Rušd y muchas otras fuentes confirman el florecimiento de la medicina y de la filosofía en el palacio almohade, donde los sabios trabajaban "al abrigo de las mentes estrechas", como indica Forcada ${ }^{59}$. Años después, en 1191, el califa al-Mansur fundó

y materialización de la belleza. La geometría del poder”, 7 Paseos por la Alhambra, Granada, 2007, pp. $485-542$.

56 ABD AL-WĀḤID AL-MARRĀKUŠĪ, Kitāb al-Mu'ŷib taljīṣ ajbār al-Magrib, "Lo admirable en el resumen de las noticias del Magrib", A. HUICI MIRANDA (trad), Colección de Crónicas Árabes de la Reconquista, Tetuán, 1955, IV, pp. 192-196. [Edición de R. DOZY, Leiden, 1847, pp. 169-171].

57 En los escritos sobre política de Ibn Rušd (que realizó el comentario de la República de Platón) se recogen asimismo las teorías farabianas del rey-filósofo y el "Estado virtuoso", que identifica con el gobierno de Yūsuf I. En M. FORCADA, op. cit., 2011, pp. 318-320. J. LIROLA DELGADO, "Ibn Rušd al-Ḥafîd, Abū 1-Walīd", Biblioteca de al-Andalus, vol. 4, Almería, 2006, pp. 517-31 (biografía).

58 Sobre el importante papel que desempeñaron en la definición ideológica almohade los médicosfilósofos, véase M. FORCADA, op.cit., 2011, pp. 316-341.

59 M. FORCADA, op.cit., 2011, p. 315. Hay que tener presente que el cultivo de las ciencias racionales, también llamadas "ciencias de los antiguos", eran mal vistas por los hombres de religión, razón por la que se mantenían en círculos muy restringidos y, en general, no trascendía fuera de los palacios y las casas. Algo que también sucedió en la Córdoba califal, S. CALVO CAPILLA, op. cit., 2014, en prensa. 
en Marraquech el primer hospital conocido del Magreb, acción glosada asimismo por al-Marrakuši. ${ }^{60}$

Estas noticias revelan que dentro del alcázar almohade de Marraquech (fig. 4) trabajaba un extenso y prestigioso cuerpo de médicos-filósofos, con los cuales el califa debatía a menudo, y que, además, disponían de una extensa biblioteca ${ }^{61}$. Aunque brevemente y con poco detalle, algunos autores han dejado testimonio de aquella biblioteca y de una madrasa palatina. Ibn Fadl Allah al-'Umari (m. 749/1349), autor egipcio bien informado, en este punto a través de un tal Ibn Sa'id, describió el palacio almohade de Marraquech. Dice al-'Umarī que en el patio del mismo, cerca de la puerta de los jardines (Bāb al-riyād), se levantaba un pabellón o qubba llamado "del Califato", estancias de huéspedes y que "sobre la misma explanada se encuentra la madrasa, construcción magnífica, con la biblioteca. Los califas Banī 'Abd al-Mu'min se reunían allí con los sabios." ${ }^{62}$ De esta escuela hablan asimismo dos autores más tardíos, León el Africano (en su Descripción de Africa, escrita hacia 1526) y Luis de Mármol (m. 1600). El primero dice ver un

"hermoso edificio para escuela de los hijos y familiares del rey, con una hermosa cámara cuadrada, rodeada de corredores y provista de bellísimas ventanas con vidrios de colores y de unos armarios de madera incrustada de fino oro y muchas pinturas en azul [...] El jardín, tan hermoso antes, es hoy muladar de la ciudad y en sendas partes de la que fue biblioteca han hecho corral de gallinas y un palomar, anidando unas y otras aves en los antiguos estantes de los libros." ${ }^{63}$

Mármol afirma que había dos madrasas, siendo una de ellas la "de los hijos del rey y de los grandes señores" donde había "una bella sala cuadrada grande, provista todo alrededor de estantes o armarios para los libros". ${ }^{64}$

De la biblioteca almohade, como sucedía con la de Córdoba, también quedan referencias de sus directores. Ibn al-Jatib cuenta en la Ihāta que

60 "Edificó en la ciudad de Marrakus un hospital, como no creo que haya en el mundo otro igual. Para ello eligió una amplia explanada en el sitio más llano de la ciudad y mandó a los albañiles que lo hiciesen de la manera más perfecta. Lo llevaron a cabo con dibujos admirables y adornos bien hechos, que aumentaron su mérito. Mandó plantar en él, también, toda clase de árboles aromáticos y frutales y le condujo muchas aguas que corrían por todas las edificaciones, además de cuatro albercas en su centro, una de ellas de mármol blanco [...]". AL-MARRĀKUŠİ, op. cit., 1955, pp. 239-40; R. DOZY,op. cit., 1847, p. 209. Poco antes Nūr al-Dīn (1146-1173) había fundado en Damasco el bello maristán que hoy todavía está en pie.

61 Sospecha Forcada que la medicina estaba muy organizada y contaba con algún tipo de institución en palacio, un lugar de enseñanza y transmisión. M. FORCADA, op. cit. 2011, p. 317; y "Síntesis y contexto de las Ciencias de los Antiguos en época almohade", P. CRESSIER et al. (eds.), Los Almohades: problemas y perspectivas, Madrid, 2005, vol. I, pp. 1091-1135 (1095).

62 IBN FAḌL ALLĀH AL-'UMAR̄̄, Masālik al-abșār fi mamālik al-amșār (Libro de los Caminos de la vista: libro acerca de los diversos reinos), vol. I, GAUDEFROY-DEMOMBYNES (trad.) L'Afrique, moins l'Egypte, Paris, 1927, p. 182-184.

63 J.L. AFRICANO, Descripción General de África y de las cosas peregrinas que alli hay, S. FANJUL (trad.), Granada, 2004, p. 170 y 171.

64 Cfr. GAUDEFROY-DEMOMBYNES, op. cit., 1927, p. 183. 


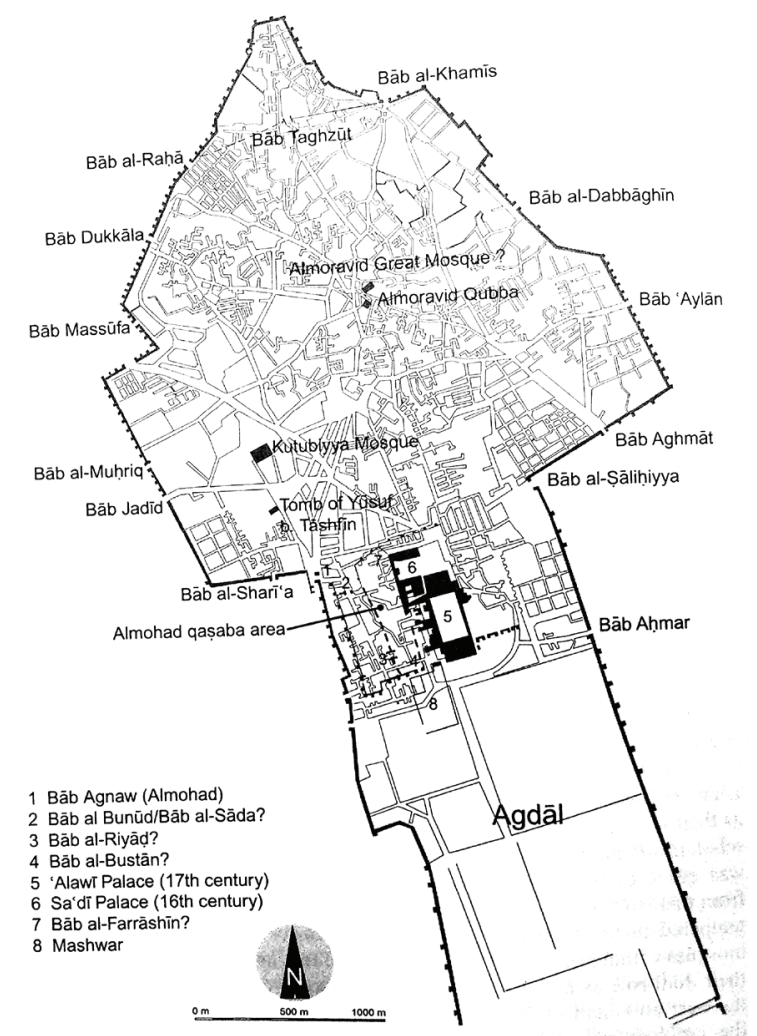

Fig. 4. Plano de Marraquech almohade. Dibujo de Piet Collet a partir del publicado por Gaudefroy-Demombynes en la traducción de Ibn Fadl Allah al-'Umarī, Masalik al-absar (L'Afrique, moins l'Egypte, Paris, 1927). Publicado por Amira K. Bennison, "Power and the city in the Islamic west from the umayyads to the almohads", en A. K. Bennison y A. L. Gascoigne (eds.), Cities in the Pre-Modern Islamic World. The Urban Impact of Religion, State and Society, 2007.

"cuando Abū Ya'qūb accedió al trono impuso [a Abū 1-‘Abbas Ahmad ibn al-Șaqr] la dirección de la biblioteca (al-jizāna al- ‘lmiyya), que era entre ellos (los almohades) uno de los cargos para los que solamente nombraban a personas de mucha valía."

Ibn al-Saqr (m. 1173), poeta y cadí de Almería, es recordado en las biografías por su amor a los libros. ${ }^{65}$

65 Se cuentan dos anécdotas de su vida que nos dan idea de su apego a los libros y a su biblioteca: el día en que los Almohades tomaron la ciudad de Marraquech (22 de marzo de 1147), el bibliófilo almeriense "perdió muchos libros que él mismo había copiado de su puño y letra, y otros de diversos copistas, cuyo valor era incalculable." Otro tanto le ocurrió en Granada, ciudad a la que se había hecho acompañar de cinco cargas (jamsat aḥmāl) de libros. Todo ello cfr. F.N. VELÁZQUEZ BASANTA, "Un Bibliófilo almeriense del siglo 


\section{Las Bibliotecas y los Maŷālis palatinos}

Quizá el dato más sugerente de los mencionados en la biografía del califa almohade Yusuf I es que éste se reunía a dialogar con Averroes y con los sabios de la corte. Desgraciadamente, no dicen los cronistas dónde lo hacía. Cuando se habla en los textos de tertulias o reuniones intelectuales suele usarse el término mâylis (pl. maŷālis). A menudo, maŷlis se asocia a sesiones o debates poéticos y literarios, amenizados con copas de vino, un entretenimiento palaciego y con frecuencia informal ${ }^{66}$. Sin embargo, las fuentes escritas informan asimismo de la existencia de tertulias, de conferencias y seminarios, de conversaciones eruditas sobre cualquier tema científi$\mathrm{co}$, literario, filosófico o teológico ${ }^{67}$. Este tipo de reuniones (maŷālis) se celebraban asimismo en los palacios privados, donde parece que los contertulios debatían con mayor libertad que en las áulicas, ante el soberano ${ }^{68}$.

De hecho, las tertulias de sabios no tenían propósitos exclusivamente filantrópicos o de pura especulación intelectual. Así, en las reuniones celebradas fuera de la corte, los anfitriones reunían a sabios de escuelas e intereses afines o bien partidarios de corrientes heterodoxas; en cuanto a los califas, se servían de los sabios para conformar la doctrina oficial y difundir una ideología determinada, como hicieron los propios califas almohades. ${ }^{69}$

La presencia de intelectuales de diversos orígenes y religiones era algo habitual en las tertulias que describimos. Hubo en concreto unas que se hicieron famosas. Las que mantenían los mutakallimūn (doctores en kalām, razón) en Bagdad en el siglo $\mathrm{X}$. Lo singular de esas tertulias era la participación de individuos de todas las reli-

XII: Abū 1-“Abbas Ahmad ibn al-Șaqr”, Al-Andalus-Magreb, 7 (1999), pp. $295-315$ (303, 308). Otro empleado en la biblioteca de Marraquech fue Ibn Šalabūn (m. 1241-2). Ambos en la Biblioteca de al-Andalus, ${ }^{\circ} 1117$ y 1082 , respectivamente.

66 D.S. RICE, "Deacon or Drink: Some Paintings from Samarra Re-examined", Arabica, 5 (1958), pp. 15-19. S.M. ALI, Arabic literary salons in the Islamic Middle ages: poetry, public performance, and the presentation of the past, Notre Dame, 2010.

67 Las tertulias podían ser de medicina, como la que mantuvo el califa al-Wātiq (gobernó entre 842 y 847) en Bagdad con un grupo de filósofos y médicos reunidos en la corte. Cuenta al-Mas‘ūdi (c. 893-956) que alWatiq amaba la "especulación filosófica y favorecía a aquellos que se dedicaban a ella (...) Disfrutaba con el desarrollo de las ciencias y sentía una gran curiosidad por las opiniones de los filósofos, tanto antiguos como modernos". Por eso preguntó cómo se adquiría el conocimiento de la medicina y sobre qué principios está basada esta ciencia. AL-MAS'ŪDI, (Murüŷy al-dahab), P. LUNDEY y C. STONE, The Meadows of Gold. The Abbasids, Londres, 1989, pp. 232-235.

68 Los maŷālis descritos por Abū Hayyān al-Tawhīīī, adīb y filósofo oriental, han permitido conocer cómo se desarrollaban esas reuniones de eruditos en las casas nobles de Bagdad a finales del siglo X. El autor, que asistió durante años (en la década de 980) a aquellas reuniones, relata en dos de sus obras, Muqābasāt (=Conversaciones) y al-Imtā' 'wa-l-mu'ānasa (= Placer y entretenimiento) numerosas sesiones donde el tema central era la filosofía y el principal interlocutor era su maestro, el filósofo Abu Sulayman al-Siyistani, de manera que dichos textos sirven también para conocer el pensamiento de ese autor. En muchas de ellas el anfitrión era el visir lbn Sa'dan. Constituyen un verdadero memorándum de la vida intelectual de Bagdad en esas fechas. M. SOBH, Historia de la Literatura árabe clásica, Madrid, 2002, pp. 666-671; M. BERGË, "Abū Ḥayyān al-Tawhīì̄’”, en J. ASHTIANY et al. (eds.), 'Abbasid Belles-Lettres, Cambridge, 1990, pp. 112-124; C. STERN, Encyclopédie de l'Islam, pp. 130-131.

69 A. MARTÍNEZ LORCA, Maestros de Occidente. Estudios sobre el pensamiento andalusí, Madrid, 2007, pp. 46-61. Véase nota 58. 
giones y sectas, infieles y ateos, judíos, cristianos y zoroastristas, que trataban todo tipo de cuestiones, incluidas las teológicas, acudiendo únicamente al razonamiento filosófico. En su origen parece que estas sesiones eran convocadas por los mu'tazilíes (seguidores de la teológica especulativa o racionalista) y en época abasí se practicaba en ellas la polémica interreligiosa y la controversia teológica ${ }^{70}$, lo que escandalizó a un alfaquí andalusí llamado Ahmad b. Muhammad b. Sa'di que acudió a dos sesiones en Bagdad ${ }^{71}$.

En la corte cordobesa del siglo $\mathrm{X}$ se documentan igualmente estas actividades. En las biografías de los sabios que frecuentaban el palacio califal a veces se dice que eran "contertulios" (munādim) del soberano ${ }^{72}$. Tampoco allí faltaban cristianos, judíos y gentes llegadas del extranjero, sin contar con el hecho de que todos aquellos doctos personajes estaban formados en varias de las ciencias de los antiguos: eran médicos además de filósofos, astrónomos y matemáticos. La difusión en al-Andalus de corrientes de pensamiento mu 'tazilí (desde el siglo IX), así como de la filosofía y las ciencias no islámicas hace sospechar que pudieron existir, en círculos privados, reuniones similares a las de los mutakallimūn de Bagdad $^{73}$.

Las bibliotecas eran uno de los lugares preferidos para celebrar estos maŷălis o reuniones. La famosa ilustración de la maqāma segunda de al-Hariri (m. 1122) en el manuscrito de 1236-7 (fig. 5) muestra una reunión de diletantes, residentes y forasteros, hablando de poesía en la biblioteca de Basra, la ciudad natal del autor. Es probable que tanto el escritor como el ilustrador (s. XIII) conocieran ese tipo de reuniones y que se inspiraran en ellas para la escena ${ }^{74}$.

Aquellas primeras bibliotecas (según se refleja en los textos, al menos) desempeñaban un importante papel en la vida cultural de las ciudades islámicas como espacios dedicados a la difusión del conocimiento. No eran meros almacenes de libros que esperaban ser leídos, eran además centros de reunión donde se daban cita sabios y eruditos. Los bibliotecarios, personas de cierta relevancia intelectual, gozaban de prestigio y de la confianza del propietario como revelan sus biografías. ${ }^{75}$ Sin embargo, apenas sabemos qué tipo de edificio las albergaba entre los siglos IX y XI, y si éste tenía ya una tipología definida y fijada. No ayuda el hecho de que la mayoría de

70 S. PINES, “A Note on an Early Meaning of the Term Mutakallim”, Israel Oriental Studies I (1971), pp. 224-240; A.M. HEINEN, "Mutakallimūn and Mathematicians”, Der Islam, 55-1, pp. 57-73.

71 Texto citado y traducido por M. ASÍN PALACIOS, Algazel: Dogmática, Moral y Ascética, Zaragoza, 1901, pp. 116-119 -previamente publicado por R. DOZY, Journal Asiatique, (1853)-; Cf. M. FIERRO, La heterodoxia en al-Andalus durante el periodo omeya, Madrid, 1987, p. 164.

72 Así llama Ibn Ŷulŷul a Ibn Umm al-Banīn, médico de ‘Abd al-Rahman III. J. VERNET, op. cit., 1968, p. 458.

73 Se plantea esta cuestión M. FIERRO, La Heterodoxia en al-Andalus durante el periodo omeya, Madrid, 1987, pp. 164-5. Sobre la persecución de los integrantes de estos círculos intelectuales a finales del siglo X, véase A. ECHEVARRÍA, Almanzor. Un califa en la sombra, Madrid, 2011, pp. 213. Sobre la repercusión del mu 'tazilismo, S. CALVO CAPILLA, "La ampliación califal de la mezquita de Córdoba: mensajes, formas y funciones", Goya, 323 (2008), p. 91.

74 Manuscrito de las Maqāmat de al-Harīrī, copiado y pintado por Yahyāa ibn Maḥmūd al-Wāsițī en Bagdad hacia 634/1236-7. Bibliothèque Nationale de France, Paris. (Arabe 5847 fol. 5v). A. SHAH (trad.), Assemblies of Al-Hariri, London, 1987, p. 6.

75 R.S. MACKENSEN, op. cit., 1932, p. 281. 


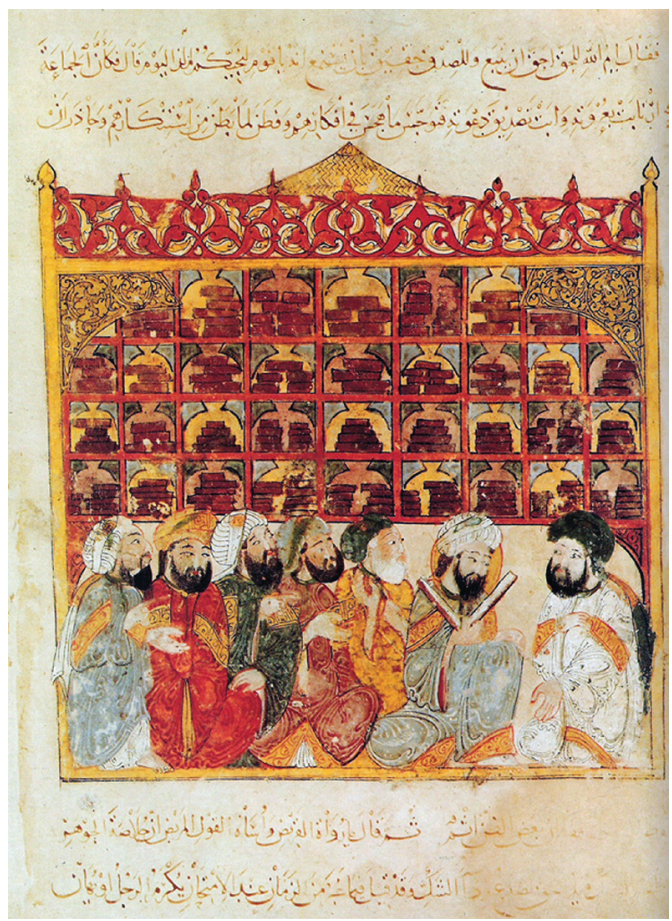

Fig. 5. Grupo de diletantes en la biblioteca de Basora, Maqamat de al-Harīrī de Basra, Manuscrito ilustrado por Yaḥyā ibn Mạ̣mūd al-Wāsiṭ̄ en Bagdad hacia 1236. Bibliothèque Nationale de France, Paris. (Arabe 5847 fol. 5v).

las bibliotecas y de los espacios vinculados al conocimiento citados por las fuentes han desaparecido sin dejar rastro.

De la biblioteca que formaba parte de la Bayt al-Hikma de Bagdad poco sabemos. Conocemos únicamente un catálogo de los libros conservados en las bibliotecas de Bagdad en el siglo X, un enorme corpus de conocimientos que inclúa obras griegas y persas traducidas al árabe, así como las libros compuestos por autores árabes. Dicho catálogo, Fihrist, fue escrito por Ibn al-Nadim hacia $987^{76}$.

En el Occidente islámico, la primera copia conocida de aquella institución de la capital abasí fue la fundada en Raqqada (Túnez, a 10km. al suroeste de Qairawan) por el emir aglabí Ibrahim II (r. 875-902). Recibió el mismo nombre, Bayt al-Hikma, y contenía, según las fuentes, una biblioteca y un lugar donde se construían instrumen-

76 R.S. MACKENSEN, op cit., 1932, pp. 279-299. El catálogo de Ibn al-Nadim introducía en el mundo islámico una tradición iniciada en el mundo antiguo por Kallimachos, autor del Pinakes, el catálogo de la biblioteca de Alexandria, publicado en la segunda mitad del siglo III a.C., y continuada por la obra escrita por Photios de Constantinopla hacia 855, titulada Bibliotheca o Myriobiblon, que recogía 280 reseñas de libros. 
tos astronómicos ${ }^{77}$. El soberano era, al parecer, muy aficionado a la astrología, razón por la que reunió allí a matemáticos y astrónomos formados en Bagdad. De aquella ciudad procedía el médico y filósofo Ishaq b. 'Imran, llamado a Qairawan para sanar al rey de la melancolía. La institución permaneció abierta tras la llegada de los fatimíes (909), si bien poco más tarde los libros y los instrumentos fueron trasladados, primero, al palacio fatimí de al-Mansuriyya y, en 969, a la nueva capital en Egipto, al-Qahira. Para Forcada no hay duda de que la actividad científica desarrollada en la corte de los últimos aglabíes es el precedente más inmediato de la corte erudita de alHakam II y el primer reflejo en Occidente del esplendor cultural de Bagdad ${ }^{78}$.

A su vez, los emires buyíes, que gobernaron Bagdad entre 945 y 1055, mantuvieron viva la actividad intelectual de la capital, fundando bibliotecas y "academias" que tomaron el testigo de la Bayt al-Hikma ${ }^{79}$ Entre 992 y 994, Sabūr lbn Ardašir fundó una gran biblioteca (dicen las fuentes que de 10,400 volúmenes) en el barrio de al-Jarj, el más grande del lado oeste de Bagdad. La biblioteca, que subsistió tras la muerte del fundador (en 1025-6) gracias al waqf instituido para su mantenimiento, era usada como "academia", y las palabras de algunos autores hacen sospechar que se construyó un edificio específicamente para albergarla. ${ }^{80}$

Al-Muqaddasi (m. c. 990) proporciona una detallada descripción de la biblioteca de otro miembro de la dinastía Buyí, 'Adud al-Dawla (949-983), gobernador del Jurasán (Irán). Su palacio de Širaz, formado por 360 habitaciones rodeadas de pabellones, albercas, acequias y jardines tenía un departamento dedicado a biblioteca:

"Hay un director, un bibliotecario, y un supervisor, escogidos entre la gente de más reputación en la ciudad. No hay ni un libro, de cualquier ciencia, que haya sido escrito hasta ese momento que no estuviera allí. Consistía en una gallería rectangular alargada en un gran vestíbulo y en habitaciones a los lados. Pegadas a los muros de la galería y de las habitaciones había estanterías de seis pies de alto por tres codos de ancho, hechas de madera y decoradas. Estas librerías tenían puertas que se abrían desde arriba, y los libros estaban ordenados en las estanterías. Había librerías para cada tema y

77 H.H. 'ABD AL-WAHHĀB, Khulāṣa Tārīkh Tūnis, Tunis, 1373/1954, p. 71; N.M. ABŪ IZZEDDIN, The Druzes: a new study of their history, faith, and society, Leiden, 1993, p. 63. Sobre Raqqada, G. MARÇAIS, Manuel d'art musulman, L'Architecture, Paris, 1926, vol. I, pp. 42-44.

78 M. FORCADA, op. cit., 2011, pp. 163-164.

79 Los emires de la dinastía buyí reconocían la autoridad del califa abasí y gobernaron gran parte de Iraq e Irán: J. SOURDEL y D. SOURDEL, Dictionnaire historique de l'Islam, Paris, 2004, pp. 166-68.

80 R.S. MACKENSEN, op. cit., 1932, pp. 288-293. Las escuelas filosóficas atenienses fueron cerradas por decreto de Justiniano en 529, al tiempo que se prohibía la enseñanza de la filosofía griega. El mismo destino corrieron las de Asia Menor (Afrodisias, por ejemplo) y las de Alejandría (aunque algunas pervivieron en uso hasta el siglo VII, como los restos hallados en Kom al-Dikka, véase ref. S. CALVO, op. cit., 2014). Abū Sulaymān al-Siŷistānī (m. ca. 985-990), bagdadí, dice en la biografía de Aristóteles que esas academias no eran sólo lugares de enseñanza: "Todos los libros de Aristóteles y sus obras sobre filosofía (hikma), lógica y otras ciencias fueron escritos en el lugar al que se trasladó, el Liceo." A. GARCÍA-JUNCEDA y R. RAMÓN GUERRERO, op. cit, 1984, p. 71. Recordemos asimismo que la Biblioteca de Alejandría fue conocida como Bayt al-Hikma por los árabes, Y. ECHE, Les bibliothèques arabes publiques et semi-publiques en Mésopotamie, en Syrie et en Égypte au Moyen-Age, Damasco, 1967, pp. 44-45. Todavía en el siglo XII, el viajero andalusí Ibn Yubayr habla de los magníficos edificios antiguos construidos para los filósofos y los maestros (ahl al-ri'āsa) y desde donde se observaban los astros, IBN YUBAYR, A través del Oriente, Riḥla,F. MAÍLLO (trad.), Barcelona, 1988, p. 55. 
catálogos que recogen los títulos de los libros; y nadie tiene acceso a ellas a menos que sea una persona de distinción". ${ }^{81}$

Poco después, el médico Ibn Sina (Avicena, m. 1037) describió la Biblioteca que en Bujara tenía el sultán Nuh ibn Mansūr (976-97), a quien curó de una enfermedad:

"Un día le pedí que me permitiera entrar en la biblioteca para consultar y leer algunos libros. Me dio permiso y pude entrar en el edificio que tenía muchas habitaciones; en cada habitación había cajas de libros apilados uno encima del otro. En una de las habitaciones eran libros de lengua árabe y poesía; en otra, libros de jurisprudencia, y así en cada habitación estaban los libros de una ciencia. Así que miré en el catálogo de libros de los antiguos y pedí los que necesitaba. Vi libros cuyos títulos casi nadie conocía y que yo veía por primera vez y no he vuelto a ver después. Leí aquellos libros y aprendí lo más útil de ellos y descubrí el estado del hombre en cada una de esas ciencias." 82

Antes de volver a al-Andalus, citemos otro caso famoso, la Dār al-Hikma fundada en El Cairo por el califa fatimí al-Hakim hacia 1005 (r. 996-1021). Según al-Maqrizi (m. 1442):

"Esta biblioteca estaba en el palacio grande y se componía de cuarenta habitaciones donde se guardaba un prodigioso número de libros de todo tipo de materias. [...] La biblioteca estaba en una sala del antiguo hospital. El califa iba a caballo y desmontaba ante un estrado en el que tomaba asiento. El bibliotecario acudía ante él y le llevaba los ejemplares del Corán más remarcables por la belleza de su epigrafía así como otros libros que pedía. Si el califa quería examinar una obra, se la llevaba y luego la devolvía. La biblioteca contenía un gran número de armarios dispuestos alrededor de la habitación y separados por tabiques, cada uno de los cuales tenía una puerta muy sólida, cerrada con cerraduras y cerrojos. Había allí más de cien mil volúmenes encuadernados y unos pocos libros encuadernados en rústica. Estaban las obras de jurisprudencia religiosa, de acuerdo con los principios de las diversas sectas, colecciones de tradiciones, tratados de gramática, de astronomía, de alquimia, las crónicas, las historias de muchos príncipes. Había varias copias de cada libro. También había obras que sus autores habían dejado inacabadas. Una hoja de papel pegada a la puerta de cada armario indicaba los manuscritos que contenía. Los Coranes se colocaron en una habitación separada situada encima de la biblioteca. Allí había calígrafos famosos. Dos copistas y dos sirvientes estaban adscritos a la biblioteca. El califa, antes de irse, se paseaba un rato para examinarla y luego se iba, no sin darle al cuidador veinte dinares". ${ }^{83}$

Por último, una vez acomodados los libros de las bibliotecas del palacio en la nueva institución, la Dār al-Hikma, se permitió a la gente visitarla:

81 AL-MUQADDASI, (Ahsan al-taqāsīm) The best divisions for knowledge of the regions, B.A. COLLINS (trad.), Londres, 2001, pp. 263-4.

82 AL-JUZAJANI, The Life of Ibn Sina = Sirat al-Shaykh al-Ra'is, W.E. GOHLMAN (ed.), New York, 1974, pp. 35-37.

83 Cfr. D. et J. SOURDEL, La civilistation de l'Islam classique, Paris, 1983, pp. 313-14. 


\begin{abstract}
"y quien quisiera copiar algo que le interesara podía hacerlo; (...) Después de que el edificio fue amueblado y decorado, y después de que todas las puertas y pasajes fueron provistos de cortinas, comenzaron a celebrarse conferencias impartidas por lectores del Corán, astrónomos, gramáticos y filólogos, así como médicos. Se contrataron vigilantes, sirvientes, criados y otros (...)". ${ }^{84}$
\end{abstract}

De nuevo aparece aquí la biblioteca como escenario de actividades intelectuales y de transmisión del saber, si bien su fundación, en el caso fatimí, tenía como fin último la difusión y propaganda de las doctrinas isma ilíes y ši 'ies ${ }^{85}$. Poco después dichas actividades se ubicarán en una nueva institución, la madrasa, para la que surgirá una tipología arquitectónica específica que iniciará su difusión desde Oriente en el siglo XI. ${ }^{86}$

Las descripciones mencionadas no dejan suponer la existencia de un mismo tipo de edificio en todos ellos para albergar la biblioteca y el lugar de estudio; de hecho, la del El Cairo se instaló, según al-Maqrizi, en una sala del antiguo hospital, lo que, por otra parte, recuerda que, posteriormente, los prototipos de maristán y de madrasa tendrán bastantes similitudes -como la existencia de un patio porticado rodeado de amplios salones. Coincide, no obstante, la manera en que se guardaban los libros, en armarios pegados a las paredes en espacios compartimentados y galerías.

En consecuencia, todavía resulta complicada la identificación de los lugares dedicados al saber entre los restos arquitectónicos de los conjuntos palatinos, por ejemplo en Samarra o en Madinat al-Zahra', por citar dos ejemplos geográficamente distantes. Incluso en palacios mejor conservados como la Alhambra de Granada, la interpretación suscita todavía debate. ¿Cómo reconocer esos espacios si no tenían una tipología fijada? Se impone usar otro tipo de indicios, desde las planimetrías y el análisis de las formas arquitectónicas, hasta las inscripciones, en el caso de existir, los restos materiales y decorativos, así como la ubicación del edificio dentro del conjunto palatino.

En la Córdoba del siglo $\mathrm{X}$, aunque ningún texto árabe le pone nombre, no cabe duda de que al-Hakam II tuvo su propia Casa de la Sabiduría, si por ello entendemos, como parece sucedió en Bagdad en el siglo IX, un conjunto de instituciones vinculadas al conocimiento y la enseñanza, una serie de espacios destinados al estudio de las ciencias (incluidas las de los "Antiguos") y a su preservación. Esos lugares habían de encontrarse repartidos entre en la ciudad palatina de Madinat al-Zahra' (construida a partir de la década de 930) y el viejo alcázar de Córdoba, las dos residencias habituales de los califas. En el nuevo palacio de al-Zahra' se instaló, según Ibn Hayyan, una escuela para el príncipe heredero, a quien acompañaban en las clases otros niños de la corte. Las fuentes indican igualmente que muchos de los sabios al servicio de al-Hakam II (entre los cuales había médicos, gramáticos, astrónomos y astrólogos, geómetras y arquitectos, botánicos, etc) residían y ejercían sus labores en la ciudad palatina; por último, si los sabios y el propio califa, tan aficionado al estudio según

84 H. HALM, The Fatimids and their Traditions of Learning, London-New York, 1997, pp. 72-73.

85 F. DAFTARY, The Ismā 'ìliss: Their History and Doctrines, Cambridge, 1992, p. 189.

86 J. PEDERSEN y G. MAKDISI, “Madrasa”, Encyclopédie de l’Islam (2), Leiden, 1986, vol. V, pp. 11191144. 
los cronistas, residían en al-Zahra', hay que suponer que el grueso de la biblioteca califal se instaló también allí. ${ }^{87}$

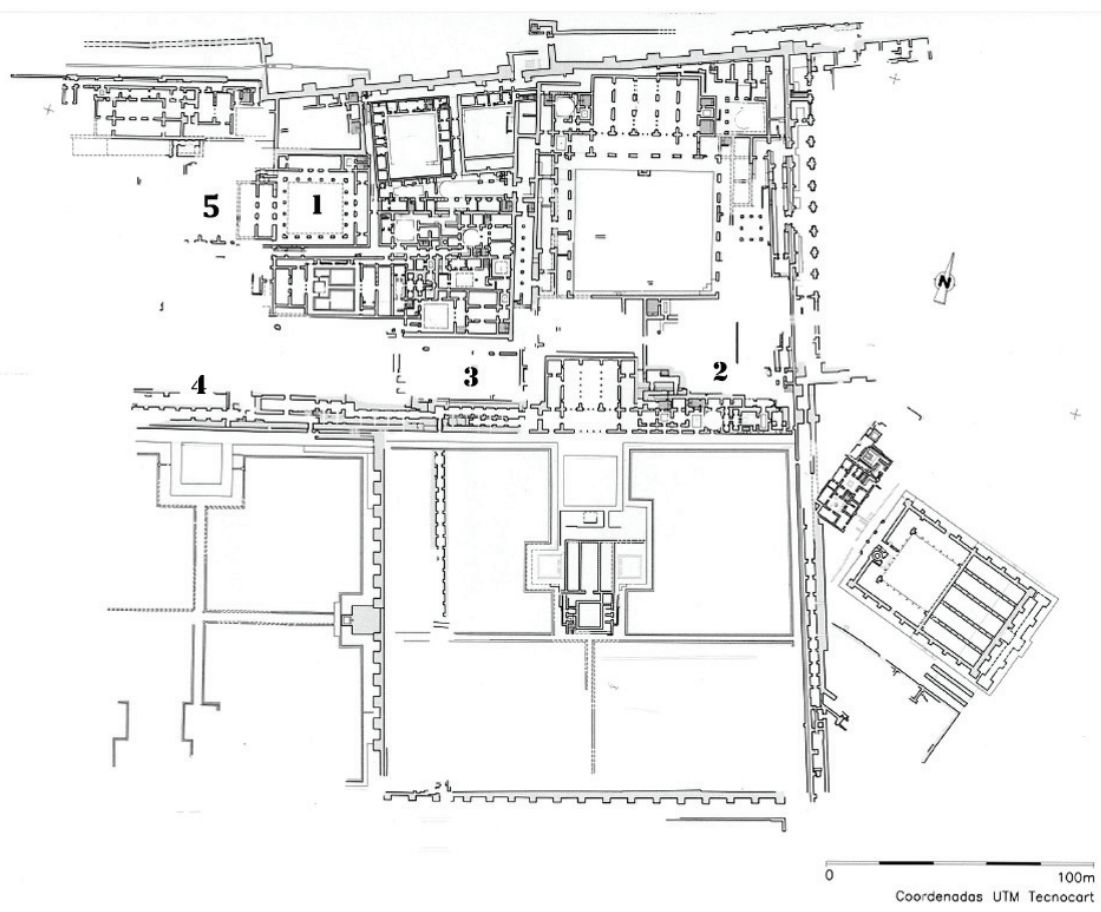

Fig. 6. Planta del área excavada de Madīnat al-Zahrā’. (Vallejo Triano, 2011).

En el conjunto palatino de Madinat al-Zahra' (fig. 6) hay una serie de edificios con características singulares que les diferencian del resto de los espacios residenciales, salones de aparato y ámbitos de administración y servicios. Se trata de los conocidos como Patio de los Pilares, Patio de los Relojes y un tercer ámbito que todavía no ha sido excavado. El primer rasgo excepcional es su tipología, que resulta totalmente novedosa en la arquitectura califal. Se trata de sendos patios rodeados de cuatro o dos pórticos de gran altura sustentados por pilares y con salas rectangulares alrededor. También llama la atención su estratégica ubicación en el palacio, la ausencia de material cerámico doméstico y de zócalos de mármol labrado entre sus ruinas, la riqueza de sus pavimentos y, sobre todo, el hallazgo en ellos de extraordinarios sarcófagos romanos con relieves de temática pagana, usados como pilas de fuentes en el centro

87 Sobre la biblioteca de la corte califal y otras bibliotecas de Córdoba, véase J. RIBERA Y TARRAGO, "Bibliófilos y bibliotecas de la España musulmana", Libros y enseñanzas en al-Andalus (1895), M.J. VIGUERA (ed.), Pamplona, 2007. Más bibliografía en S. CALVO CAPILLA, op. cit., 2014; y "Madīnat alZahrā’ y la observación del tiempo: el renacer de la Antigüedad Clásica en la Córdoba del siglo X”, Anales de Historia del Arte, Número extraordinario, 23 (2013), pp. 131-60. 


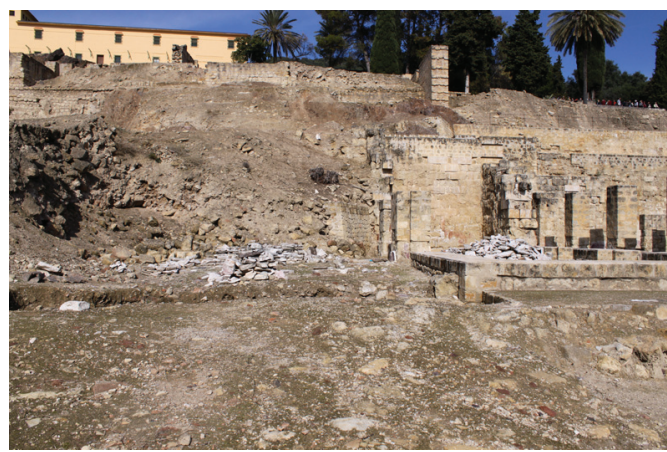

Fig. 7. Patio de los Pilares y ámbito adyacente sin excavar, llamado Salón de las Dobles Columnas.

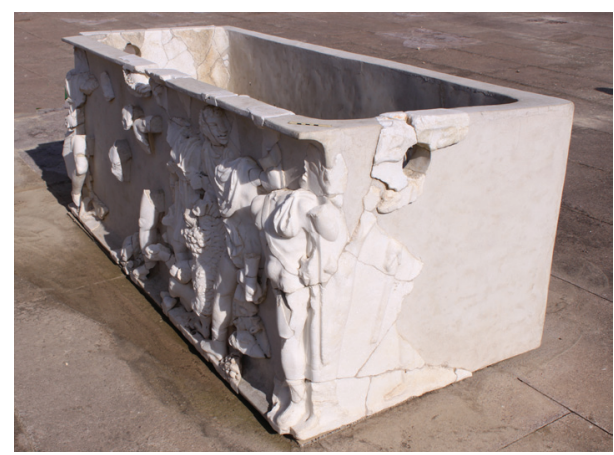

Fig. 8. Sarcófago de Meleagro, hallado en el Patio de los Pilares de Madīnat alZahrā'.

del patio ${ }^{88}$. Varios de los sarcófagos están decorados con escenas de filósofos y musas que acompañan al difunto, heroizado a través del cultivo del saber. Los filósofos aparecen rodeados de libros (en forma de rollos), en actitud de leer o como docentes.

En el Patio de los Pilares (fig. 7), ubicado a los pies de la residencia califal (Dār al-Mulk), se encontró el sarcófago decorado con la escena de la caza del jabalí por Meleagro (fig. 8); es un patio de enorme tamaño, rodeado de cuatro pórticos sobre pilares y construido en una segunda fase de la ciudad palatina, pues se amortizaron para ello unas viviendas previas. Adosado al oeste del patio se encuentra el llamado "Salón de las Dobles Columnas", todavía sin excavar (fig. 7). Entre los restos de este gran salón se han encontrado paneles de mármol labrados, teselas de mosaicos dorados y fragmentos de inscripciones coránicas, lo que hace intuir su riqueza y excepcionalidad $^{89}$. El Patio de los Relojes está situado al borde de la terraza superior, con vistas sobre la ciudad, la mezquita aljama y el llamado Jardín Alto (junto al cual se levanta el Salón Rico). Su nombre viene del hallazgo en él de fragmentos de tres cuadrantes solares, junto a los cuales también se encontraron un herma de Heracles niño y fragmentos de un sarcófago decorado con filósofos y musas que acompañan al difunto (o difuntos) a la Puerta del Hades (fig. 9 y 10). En el área todavía no escavada que se sitúa entre la vivienda llamada "de Ya'far" y el llamado Jardín bajo, al este del conocido como Salón Rico, se hallaron fragmentos de otros sarcófagos, de los cuales el más relevante es un sarcófago de grandes dimensiones (con figuras casi de tamaño natural) donde se representa, de nuevo, a filósofos y musas. Todas ellas son piezas romanas de excepcional calidad y tamaño ${ }^{90}$.

88 S. CALVO CAPILLA, op. cit., 2014.

89 Desconocemos la función del Salón de las Dobles Columnas, y sólo las futuras excavaciones aclararán la disposición de esta área. Sobre los materiales hallados véase A. VALLEJO, La ciudad califal de Madinat al-Zahra: arqueología de su excavación, Córdoba, 2010, pp. 364, 431 y 458.

90 J. BELTRÁN FORTES et al., Los sarcófagos romanos de Andalucía, Corpus de esculturas del Imperio Romano, Murcia, 2006, vol. 1, fasc. 3, pp. 126-144. 

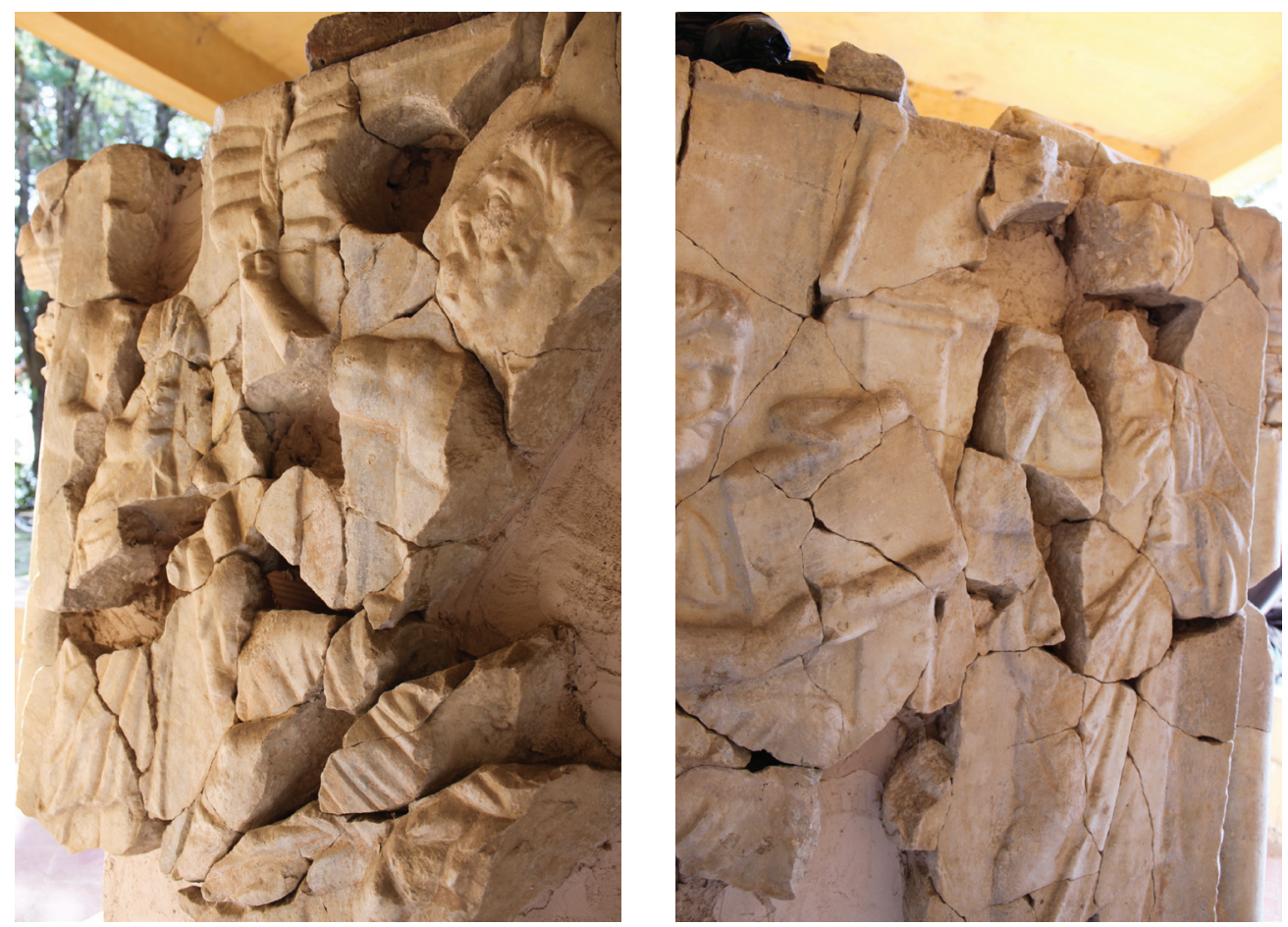

Figs. 9-10. Laterales del sarcófago de la Puerta del Hades, hallado en el Patio de los Relojes de Madīnat al-Zahrā'.

Lo mucho que ya conocemos sobre el mecenazgo y el impulso de las ciencias, en particular la recuperación de los saberes antiguos, en la corte de al-Hakam II refuerza la idea de que las figuras representadas sobre esos sarcófagos eran reconocidas por los miembros de la corte como imágenes de la Antigüedad, como sabios grecolatinos similares a los que figuraban en los frontispicios de algunos manuscritos ilustrados que circulaban desde la Antigüedad Tardía por el Mediterráneo. En consecuencia, la reutilización de estos sarcófagos historiados como pilas de fuentes en determinados edificios de la ciudad fue un acto consciente y cargado de contenido, que trascendía su valor estético y de spolia..$^{91}$ Colocados en espacios dedicados al cultivo y conservación del conocimiento, estos sarcófagos extraídos de las ruinas romanas cobrarían todo su sentido como ilustración de la herencia cultural de la Antigüedad y de la Hispania preislámica, utilizada por los omeyas cordobeses en la construcción ideológica del Califato.

91 A ello se suma la pervivencia de algunas imágenes de la mitología grecolatina asociadas a los astros, como las estatuas femeninas que coronaban las puertas de Madinat al-Zahra' y Córdoba. S. CALVO CAPILLA, "Madīnat al-Zahrā'”, 2013, pp. 134-135. 
Concluimos en la Alhambra de Granada con unas palabras de Ibn al-Jațīb, el artífice del proyecto de la madrasa palatina de Muhammad V, según cuenta él mismo en sendas biografías, la suya y la del sultán ${ }^{92}$. Diversos indicios apuntan a que aquella escuela palatina, un ámbito dedicado de forma genérica al más alto grado del saber y del conocimiento, se localiza en el Patio de los Leones, tal y como reveló el estudio de Ruiz Souza en 2001. ${ }^{93}$ Como indicaba el investigador en su artículo, una comparación de la planta de las madrasas del Magreb y de Egipto con el Patio de los Leones muestra a simple vista las similitudes, de la misma manera que algunas de las descripciones de las bibliotecas islámicas mencionadas antes podrían referirse a la Sala de los Reyes, con sus habitaciones y armarios (fig. 11).

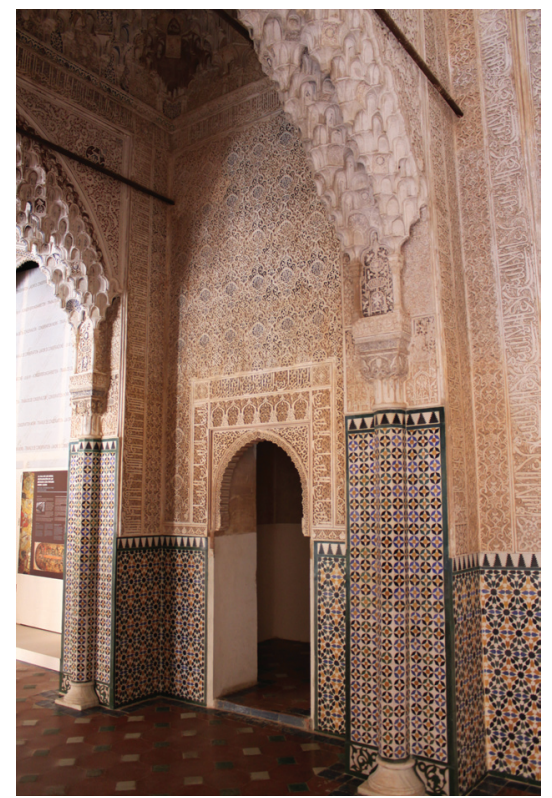

Fig. 11. Sala de los Reyes, La Alhambra de Granada.

En uno de los poemas más extensos de la Sala de Dos Hermanas, situado sobre el zócalo, el salón no sólo se llama a sí mismo jardín (rawde y sublime palacio, sino que dice ser también "un amplio lugar de reunión (nādiya)", utilizando un vocablo (de la raíz $n a d \bar{a}$ ) que alude a un círculo, asamblea o grupo de estudio, de manera análoga a maŷlis ${ }^{94}$. En este contexto, cobra mayor valor el fragmento tomado de

92 Párrafos recogidos por D. CABANELAS RODRÍGUEZ, "La madraza árabe de Granada y su suerte en época cristiana”, Cuadernos de la Alhambra, 24 (1988), pp. 39-40; Cfr. J.C. RUIZ SOUZA, "El palacio de los Leones de la Alhambra: ¿Madrasa, Zâwiya y Tumba de Muhammad V?’, Al-Qantara, 22-1 (2001), pp.105-106.

93 J.C. RUIZ SOUZA, op. cit., 2001. Matiza C. ROBINSON que quizá se tratara de una especie de $D \bar{a} r$ al-Hikma, en "Marginal Ornament: Poetics, Mimesis, and Devotion in the Palace of The Lions", Muqarnas (2008), pp. 185-204.

94 J.M. PUERTA VÍLCHEZ, Leer la Alhambra, Granada 2010, pp. 213-14, Línea 19 del poema. 
Șa ‘id al-Andalusī que Ibn al-Jațib, uno de los hombres más ilustres e ilustrados del siglo XIV, inserta en su Markaz al-ihătata, texto donde se dan cita de nuevo Alejandro Magno y Aristóteles y que insiste en la importancia de dar una elevada educación a los príncipes:

"Entre otros hechos de la vida de Aristóteles, dice que el rey Filipo le había tomado como preceptor de sus siete hijos, de los cuales Alejandro era el menor. Aristóteles le enseñaba la filosofía y las disciplinas del quadrivium. Cierto día, quiso probar su inteligencia para saber cuál de ellos sería digno de ocupar el trono. Tomó, pues, a cada uno de ellos en privado y le dijo: "Cuando tú seas rey, en lugar de tu padre, si aún estoy vivo, ¿qué harás conmigo?”. Y cada uno de ellos fue respondiendo lo que le venía a la mente: que sería ministro, etc. Cuando estuvo a solas con Alejandro y le hubo hecho esta pregunta, el niño respondió: «Haré lo que un hombre como yo debe hacer con un hombre como tú." Aristóteles supo entonces que este niño [Alejandro] era el más noble de los siete y se lo hizo saber a Filipo. Esta fue la causa de la ascensión de Alejandro al trono. Una vez erigido rey, en efecto, éste consideró a Aristóteles como a su padre; y seguía sus consejos en todas sus actuaciones" ${ }^{95}$.

95 R. BLACHÈRE, op. cit., 1935, pp. 67-68; cfr., E. LLAVERO RUIZ Y A. MARTÍNEZ LORCA, op. cit., 2000, pp. 87-88. (véase nota 38). 